\title{
A quantitative approach to nucleophilic organocatalysis
}

\author{
Herbert Mayr ${ }^{*}$, Sami Lakhdar, Biplab Maji and Armin R. Ofial
}

\section{Review}

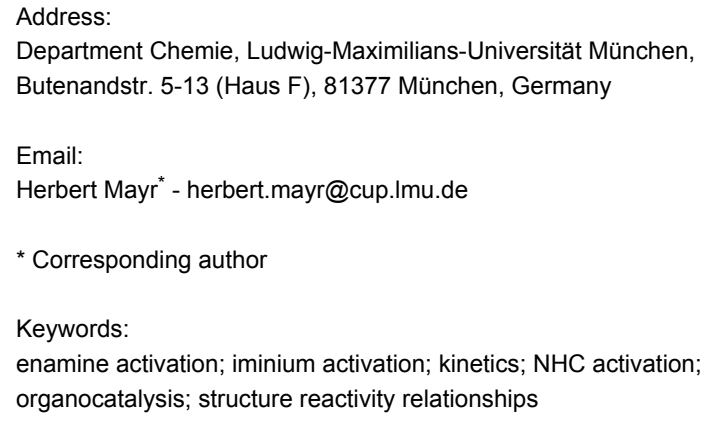

\begin{abstract}
The key steps in most organocatalytic cyclizations are the reactions of electrophiles with nucleophiles. Their rates can be calculated by the linear free-energy relationship $\log k\left(20^{\circ} \mathrm{C}\right)=s_{\mathrm{N}}(E+N)$, where electrophiles are characterized by one parameter $(E)$ and nucleophiles are characterized by the solvent-dependent nucleophilicity $(N)$ and sensitivity $\left(s_{\mathrm{N}}\right)$ parameters.

Electrophilicity parameters in the range $-10<E<-5$ were determined for iminium ions derived from cinnamaldehyde and common organocatalysts, such as pyrrolidines and imidazolidinones, by studying the rates of their reactions with reference nucleophiles. Iminium activated reactions of $\alpha, \beta$-unsaturated aldehydes can, therefore, be expected to proceed with nucleophiles of $2<N<14$, because such nucleophiles are strong enough to react with iminium ions but weak enough not to react with their precursor aldehydes. With the $N$ parameters of enamines derived from phenylacetaldehyde and MacMillan's imidazolidinones one can rationalize why only strong electrophiles, such as stabilized carbenium ions $(-8<E<-2)$ or hexachlorocyclohexadienone $(E=-6.75)$, are suitable electrophiles for enamine activated reactions with imidazolidinones. Several mechanistic controversies concerning iminium and enamine activated reactions could thus be settled by studying the reactivities of independently synthesized intermediates.
\end{abstract}

Kinetic investigations of the reactions of N-heterocyclic carbenes (NHCs) with benzhydrylium ions showed that they have similar nucleophilicities to common organocatalysts (e.g., $\mathrm{PPh}_{3}$, DMAP, DABCO) but are much stronger (100-200 kJ mol ${ }^{-1}$ ) Lewis bases. While structurally analogous imidazolylidenes and imidazolidinylidenes have comparable nucleophilicities and Lewis basicities, the corresponding deoxy Breslow intermediates differ dramatically in reactivity. The thousand-fold higher nucleophilicity of 2-benzylidene-imidazoline relative to 2-benzylidene-imidazolidine is explained by the gain of aromaticity during electrophilic additions to the imidazoline derivatives. O-Methylated Breslow intermediates are a hundred-fold less nucleophilic than deoxy Breslow intermediates. 


\section{Review \\ Introduction}

The most comprehensive nucleophilicity and electrophilicity scales presently available, are based on Equation 1, in which electrophiles are characterized by one solvent-independent parameter $E$, and nucleophiles are characterized by two solventdependent parameters, the nucleophilicity parameter $N$ and the sensitivity parameter $s_{\mathrm{N}}[1-3]$.

$$
\log k\left(20^{\circ} \mathrm{C}\right)=s_{\mathrm{N}}(E+N)
$$

By defining benzhydrylium ions, structurally related quinone methides, and arylidenemalonates as reference electrophiles, which cover a reactivity range of 32 orders of magnitude corresponding to relative reaction times from nanoseconds to $10^{15}$ years, we have been able to compare nucleophiles of widely differing structure and reactivity [4]. As illustrated by Figure 1, this method allows us to characterize strong nucleophiles, such as carbanions and ylides, by their reactivities toward weak electrophiles, and to characterize weak nucleophiles, such as nonactivated alkenes, by their reactivities toward strong electrophiles. Recently we have explicitly outlined the reasons why we prefer Equation 1, a nonconventional version of a linear free-energy relationship, which defines nucleo- philicities as the negative intercepts on the abscissa, over the conventional (mathematically equivalent) linear free-energy relationship depicted in the red frame at the top of Figure 1 [5].

The reactivity scales, developed on this basis, have not only be employed for designing organic syntheses [6-18], but were also helpful for rigorous examinations of general concepts of organic reactivity, such as the "Reactivity Selectivity Principle" [19], the "HSAB Treatment of Ambident Reactivity" [20] and the changes of mechanisms in nucleophilic aliphatic substitutions $[21,22]$. In this essay, we will illustrate applications of Equation 1 in nucleophilic organocatalysis.

\section{Iminium activated reactions}

A key step of the commonly accepted catalytic cycle for iminium activated reactions (Figure 2 ) is the attack of a nucleophile 4 on the intermediate iminium ion (3), which can be treated by Equation 1 as indicated in the bottom right of Figure 2 [23-28].

In order to predict which nucleophiles $\mathbf{4}$ are suitable reagents for such transformations because they are strong enough to react with iminium ions $\mathbf{3}$, but weak enough not to react with

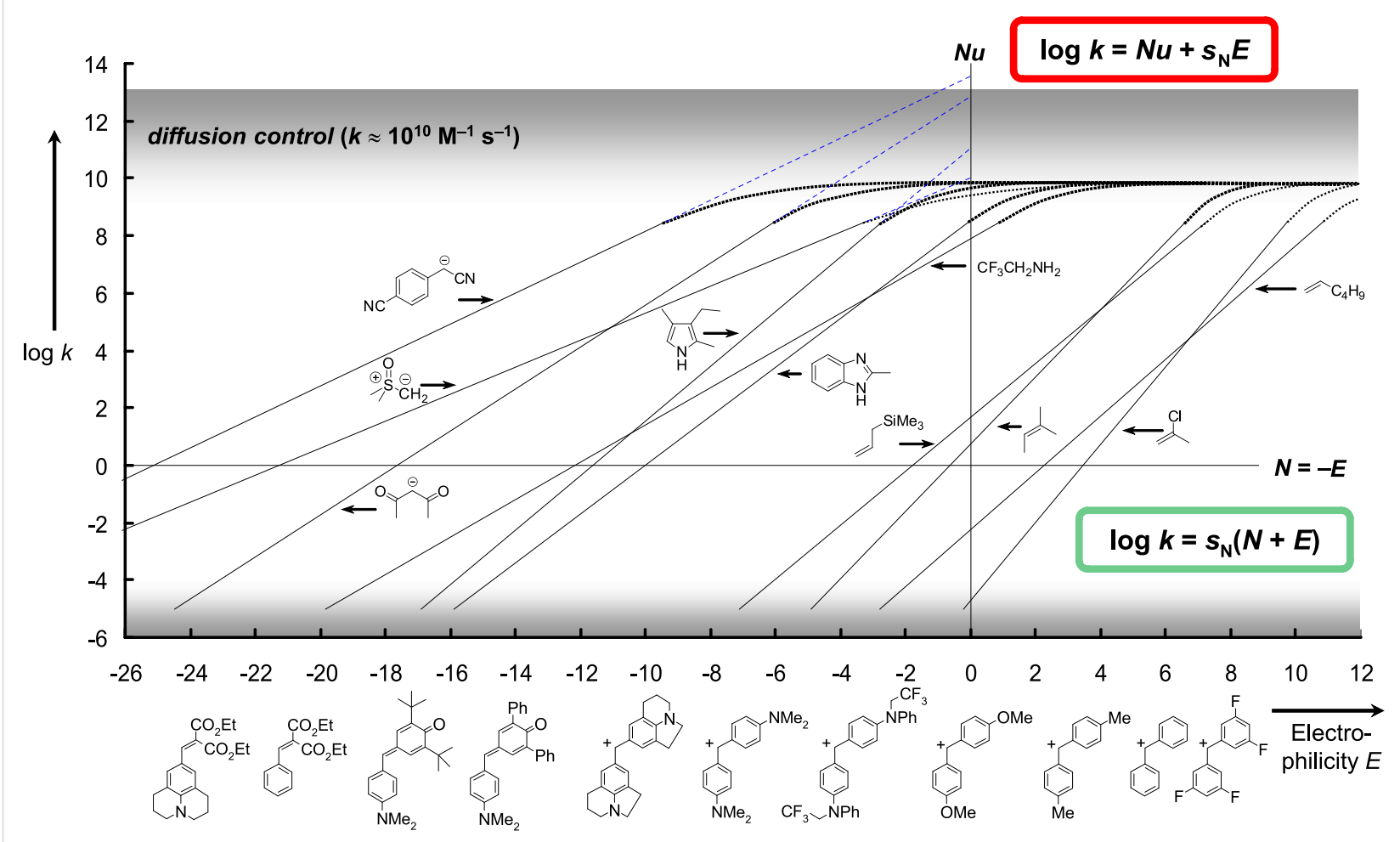

Figure 1: Second-order rate constants for reactions of electrophiles with nucleophiles. 


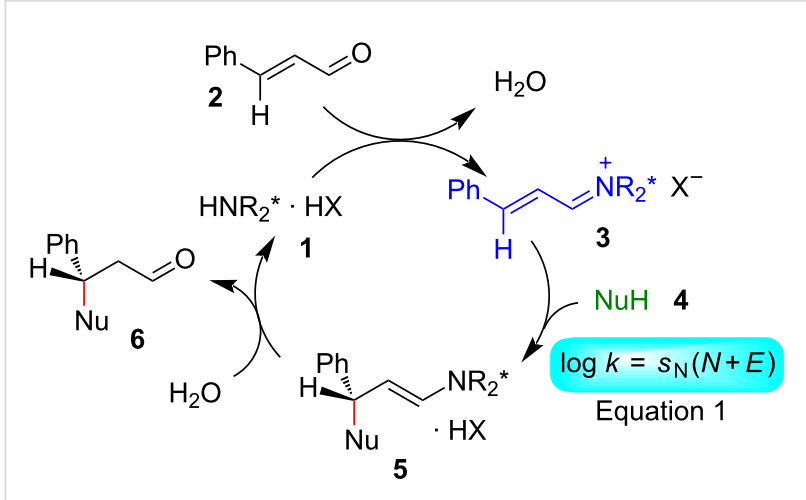

Figure 2: Mechanism of amine-catalyzed conjugate additions of nucleophiles [23-28].

the precursor carbonyl compounds (e.g., 2), it was necessary to determine the reactivity parameters $N$ and $s_{\mathrm{N}}$ of potential nucleophilic substrates $\mathbf{4}$ and the electrophilicity parameters $E$ of iminium ions 3 .

Iminium triflates, tetrafluoroborates, or hexafluorophosphates were synthesized as stable salts according to literature procedures [29-35]. Cinnamaldehyde-derived iminium ions $\mathbf{3}$ are particularly suitable for kinetic investigations because their reactions with nucleophiles can easily be followed photometrically by monitoring the decay of their absorbance at $370 \mathrm{~nm}$ (as exemplified in Figure 3a,b). By using the nucleophiles (for example 7a) in large excess, pseudo-first-order kinetics were achieved, and the first-order rate constants $k_{\text {obs }}\left(\mathrm{s}^{-1}\right)$ were derived from the exponential decays of the iminium ions 3 (Figure $3 \mathrm{c}$ ). Plots of $k_{\text {obs }}$ versus the concentrations of the nucleophiles (Figure 3d) were linear, with their slopes giving the second-order rate constants $k_{2}\left(\mathrm{M}^{-1} \mathrm{~s}^{-1}\right)$ $[35,36]$.

For the investigations of reactions of the iminium ions on the micro- and nanosecond time scale, laser flash spectroscopy was employed [37]. As tertiary phosphines $\mathrm{PR}_{3}(\mathbf{1 0})$ are known to be excellent photonucleofuges [38-41], the stable iminium salts 3-PF 6 were treated with tertiary phosphines $\mathbf{1 0}$ at room temperature to give the enamino-phosphonium ions 11 instantaneously (Figure 4a). Their irradiation with $7 \mathrm{~ns}$ laser pulses $(266 \mathrm{~nm})$ regenerated the iminium ions, the decay of which was monitored photometrically in the presence of variable concentrations of nucleophiles (Figure $4 b$ ).

As above, the second-order rate constants for the reactions of the iminium ions with nucleophiles were obtained as the slopes<smiles>COC1=CCCC(OC)O1</smiles><smiles>CO[Ga]O[Mg]C1CCCOC1=O</smiles>

$8 \mathbf{a}$<smiles>CC1(C)NC(=O)[C@H](Cc2ccccc2)N1/C=C/C(c1ccccc1)C1CCCOC1=O</smiles>

9a b)

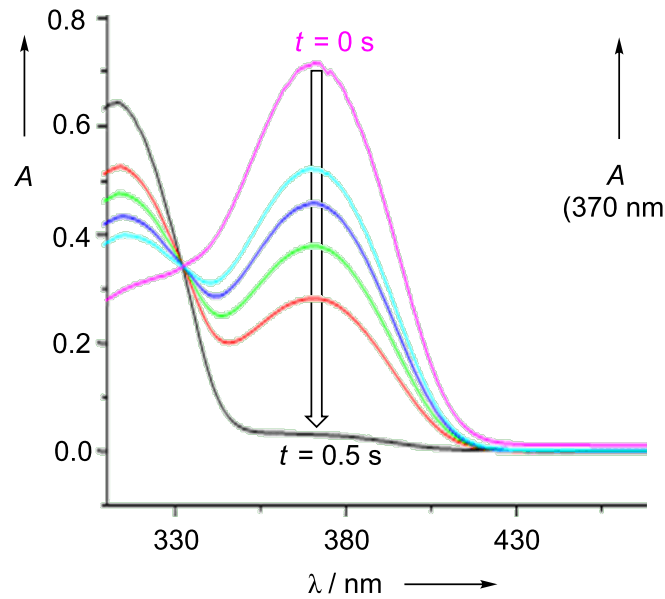

c)

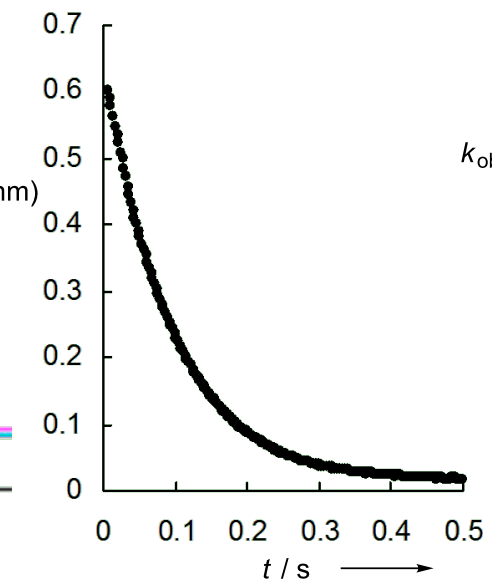

d)

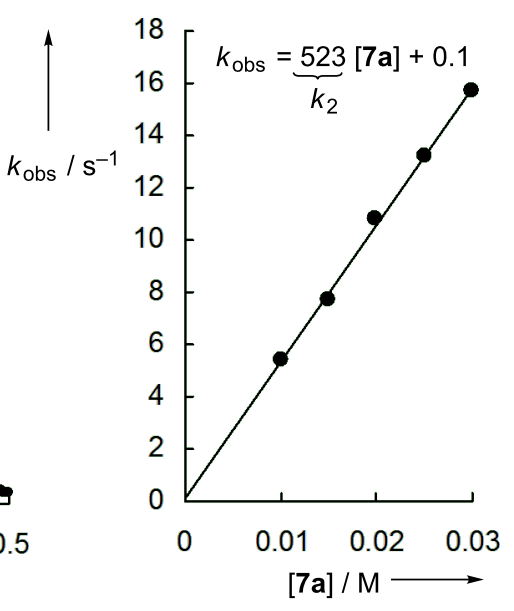

Figure 3: Kinetics of the reactions of the iminium ion 3a with the silylated ketene acetal $7 \mathbf{a}$ [35]. 


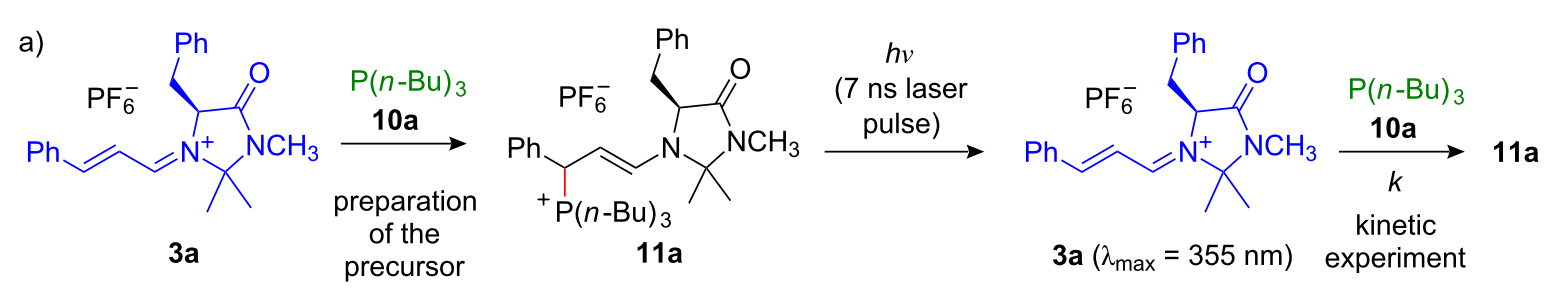

b)

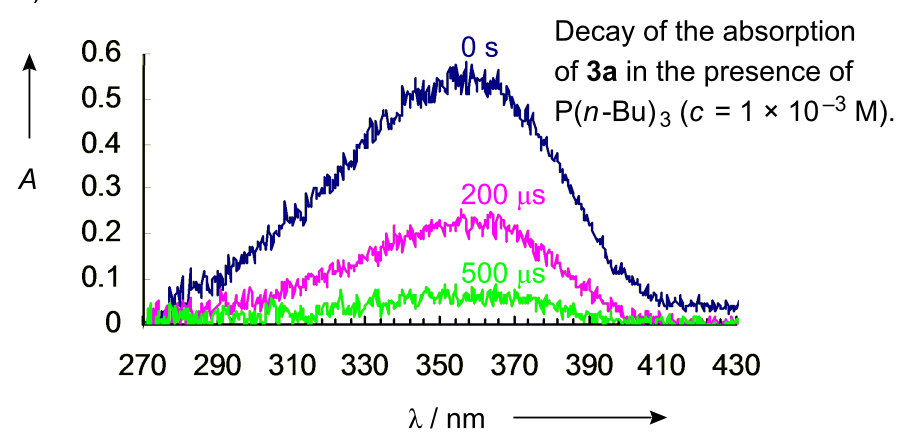

c)

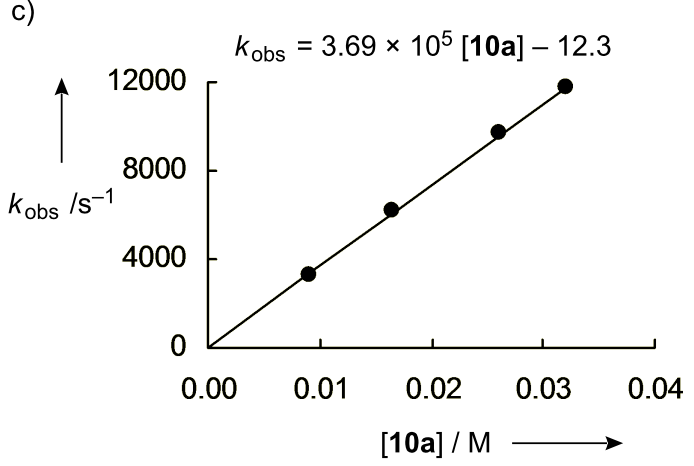

Figure 4: Laser flash photolytic generation of iminium ions $3 \mathbf{3 a}$

of the plots of the first-order rate constants $k_{\text {obs }}$ versus the concentrations of the corresponding nucleophiles (Figure 4c).

The fair correlations of $\left(\log k_{2}\right) / s_{\mathrm{N}}$ versus the nucleophilicity parameters $N$ with slopes of unity in Figure 5 indicate the applicability of Equation 1, and is a further evidence that the reactivity parameters $N$ and $s_{\mathrm{N}}$, which are derived from reactions with benzhydrylium ions, also hold for reactions with iminium ions 3.

Analogous experiments showed that the cinnamaldehydederived iminium ions $\mathbf{3 a}-\mathbf{i}$ cover a reactivity range of five orders of magnitude; the iminium ion $\mathbf{3 b}$, derived from MacMillan's generation II catalyst, turned out to be by far the most reactive one of this series (Figure 6) $[37,42,43]$.

When comparing the $N$ parameters of substrates previously employed in iminium activated reactions (Figure 7) $[35,42,44-$ $52]$, one can see that they are characterized by nucleophilicity parameters in the range $2<N<14$. As Equation 1 describes only one step of the catalytic cycle in Figure 2, we do not claim that $N$ parameters in the indicated range represent a sufficient criterion for the selection of potential substrates in iminium activated reactions. It will be difficult, however, to find suitable nucleophilic substrates outside this range, as stronger nucleophiles will either react with the carbonyl compounds directly or inhibit the formation of the iminium ions due to their high basicity. Weaker nucleophiles, on the other hand, will not be able to attack iminium ions $\mathbf{3}$; exceptions may be expected for

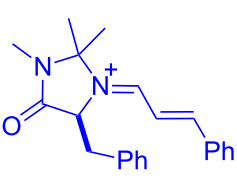

$3 a$

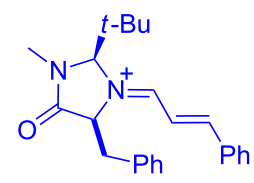

$3 b$

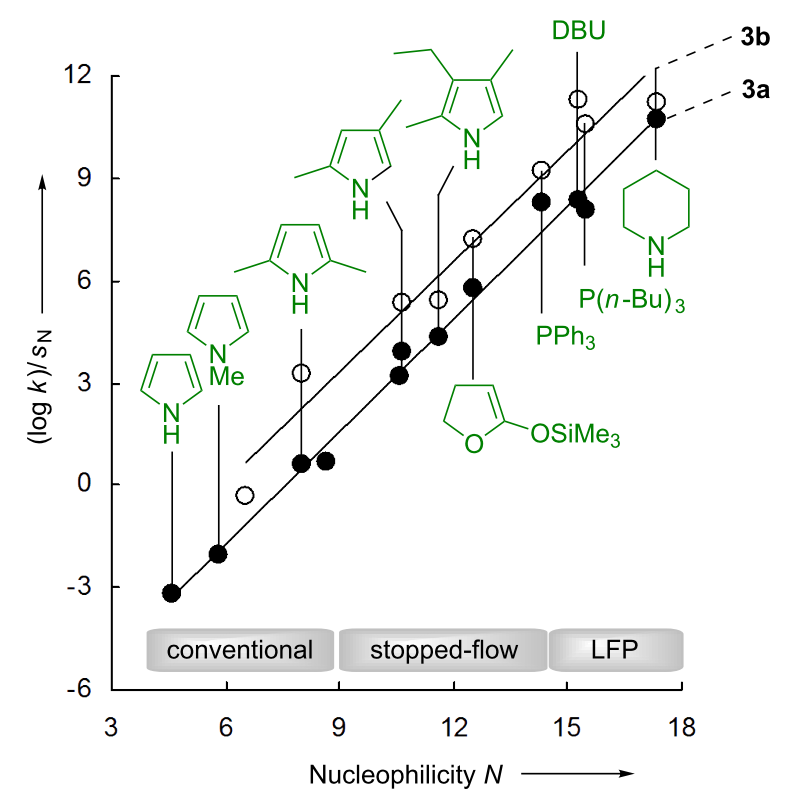

Figure 5: Correlations of the reactivities of the iminium ions $3 a$ and $3 \mathbf{b}$ toward nucleophiles with the corresponding $N$ parameters - LFP = laser flash photolysis. 


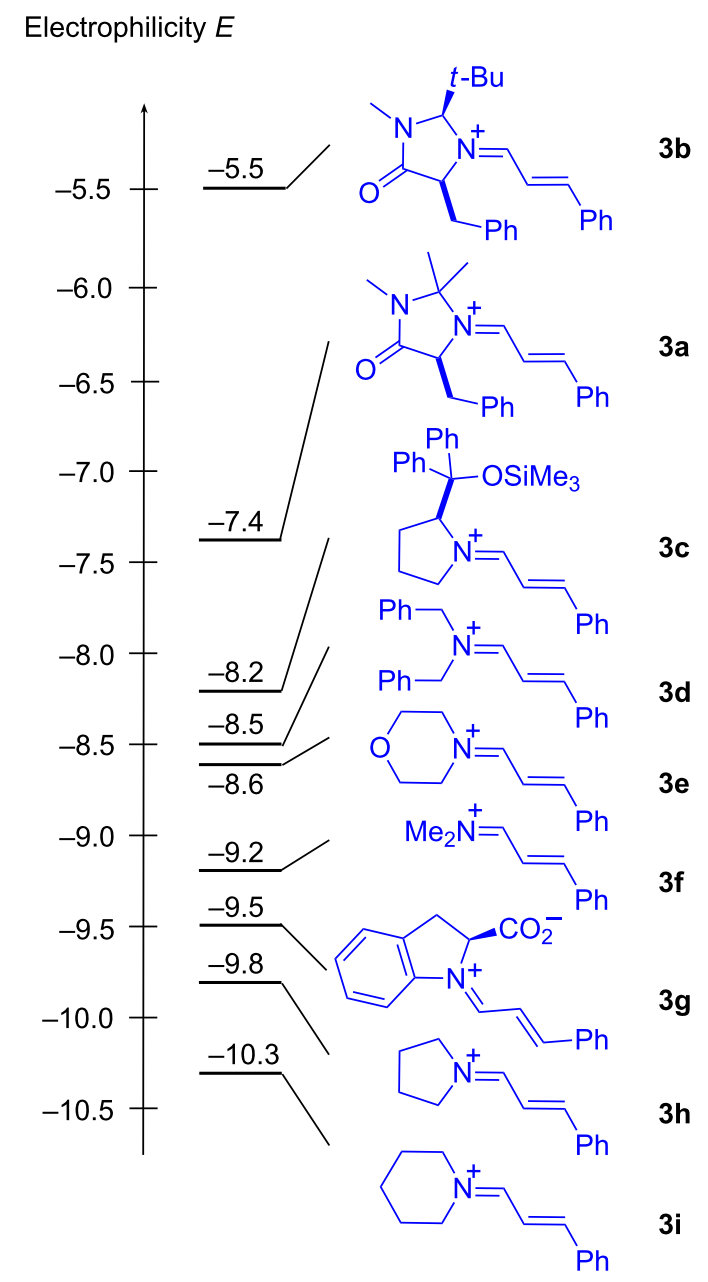

Figure 6: Comparison of the electrophilicities of cinnamaldehydederived iminium ions $\mathbf{3 a} \mathbf{a}-\mathbf{3 i}$.

substrates which undergo concerted pericyclic reactions with the iminium ions and therefore do not follow Equation 1 [53]

Let us now consider the role of counterions, as the imidazolidinone catalyzed reactions of cinnamaldehyde with pyrrole were reported to proceed with high yields and enantioselectivities, when using trifluoroacetic acid as cocatalyst, while yields and enantioselectivities are low with strong acids, such as $\mathrm{CF}_{3} \mathrm{SO}_{3} \mathrm{H}$, TsOH, or $\mathrm{HCl}$, as cocatalysts $[46,54,55]$.

Figure 8 shows that the rates of the reactions of $\mathbf{3 a}-\mathrm{X}$ with 2-(trimethylsiloxy)-4,5-dihydrofuran (7b) were only slightly affected by the nature of the counterions $\mathrm{X}^{-}\left(\mathrm{X}^{-}=\mathrm{PF}_{6}^{-}, \mathrm{BF}_{4}^{-}\right.$, $\mathrm{TfO}^{-}, \mathrm{Br}^{-}, \mathrm{CF}_{3} \mathrm{CO}_{2}^{-}$) [56].

In contrast, the reaction of $\mathbf{3 a - X}$ with 3-ethyl-2,4-dimethylpyrrole (kryptopyrrole, 12a) was considerably faster when
$\mathrm{CF}_{3} \mathrm{CO}_{2}^{-}$was present than when less basic counterions were employed. The acceleration of the reaction by increasing the concentration of $\mathrm{CF}_{3} \mathrm{CO}_{2}{ }^{-}$demonstrated that $\mathrm{CF}_{3} \mathrm{CO}_{2}{ }^{-}$acted as a general base to deprotonate the Wheland intermediate $13 \mathbf{a}^{+}$ and thus suppresses its retroaddition with regeneration of the pyrrole 12a and the iminium ion 3a. Rate constants observed at variable concentrations of $\mathrm{CF}_{3} \mathrm{CO}_{2}{ }^{-}$allowed us to calculate the second-order rate constants $k_{2}$ for the attack of the iminium ion 3a at the pyrroles 12a-12f, and Figure 9 shows that the observed rate constants agree, within a factor of five, with those calculated by using Equation 1.

We consider this agreement remarkable, as the $E$ parameter for 3a has been derived from rate constants with a large variety of nucleophiles [37] and the $N$ and $s_{\mathrm{N}}$ parameters of the pyrroles 12a-12f have been derived from their reactivities toward benzhydrylium ions [57]. As Equation 1 is employed for calculating absolute rate constants $k_{2}$ in a reactivity range of 40 orders of magnitude with only three parameters, $N, s_{\mathrm{N}}$, and $E$, one generally has to tolerate deviations up to factors of 10 to $100[2,3,5]$.

However, an even better agreement between calculated and experimental values was observed for the reactions of $\mathbf{3 a}$ with imidazoles 15 (Figure 10) [58].

These additions are highly reversible, however, and the adducts could only be isolated when the reaction mixtures containing 16 (for $\mathrm{R}^{2}=\mathrm{H}$ ) were worked up with dry $\mathrm{K}_{2} \mathrm{CO}_{3}$. Aqueous workup led to regeneration of the reactants. Vicario's report that imidazoles, in contrast to triazoles and tetrazoles, do not readily undergo iminium activated additions to $\alpha, \beta$ unsaturated aldehydes can thus be explained by the low acidity of imidazolium ions [59]. Unlike triazolium and tetrazolium ions, imidazolium ions are unable to transfer a proton to the enamine unit in $\mathbf{1 6}$ (corresponding to $\mathbf{5}$ in the general Figure 2), which is necessary to close the catalytic cycle shown in Figure 2 [60].

General base catalysis appeared also to be essential for iminium activated reactions of $\alpha, \beta$-unsaturated aldehydes with enamides 17. By studying the kinetics of the reactions of enamides $\mathbf{1 7}$ with benzhydrylium ions 18 (Figure 11) we determined the reactivity parameters $N$ and $s_{\mathrm{N}}$ for these $\pi$-nucleophiles, which are listed in Figure 12 [61].

Figure 12 shows that the nucleophilicities $N$ of the enamides $\mathbf{1 7}$ are comparable to those of silylated enol ethers, in between those of allylsilanes and enamines. Accordingly, we expected them to react readily with the iminium ions $\mathbf{3}$ at room temperature. 


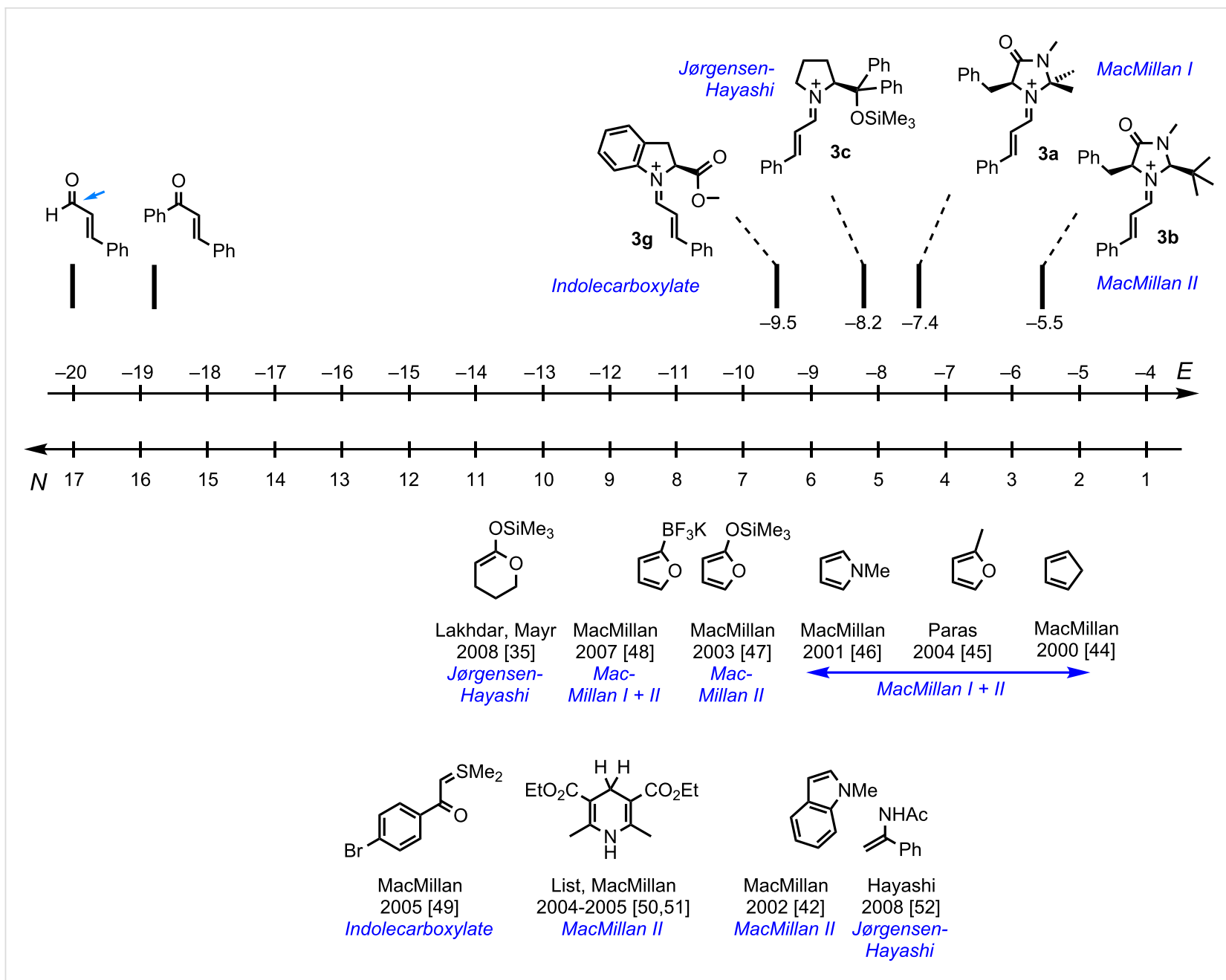

Figure 7: Nucleophiles used in iminium activated reactions [35,42,44-52].

However, when the iminium triflates or hexafluorophosphates 3a and $\mathbf{3 b}\left(\sim 5 \times 10^{-5} \mathrm{M}\right)$ were combined with 25 equivalents of the enamides $17 \mathbf{b}$ and $17 \mathbf{g}$ in $\mathrm{CH}_{2} \mathrm{Cl}_{2}$ or $\mathrm{CH}_{3} \mathrm{CN}$, no consumption of the iminium ions was observed [61]. These reactions took place in the presence of 2,6-lutidine, however, indicating the need of general base assistance. By studying the kinetics of these reactions in the presence of variable concentrations of 2,6lutidine, we were able to determine $k_{2}$, the rate constant for the attack of the iminium ions 3 at the enamides 17. As shown in Figure 13, the rate constants thus determined, agree within a factor of 3 with those calculated by Equation 1 using the $N$ and $s_{\mathrm{N}}$ parameters of enamides $\mathbf{1 7}$, which have been derived from their reactions with the benzhydrylium ions $\mathbf{1 8}$ (Figure 11 and Figure 12) [61].

These observations explain why strong acids, such as $p$ - $\mathrm{TsOH}$, proved not to be suitable cocatalysts for iminium activated reactions of $\alpha, \beta$-unsaturated aldehydes with enamides [62]. The demonstration of general base catalysis for these reactions furthermore rules out Hayashi's proposal of a concerted ene reaction for the formation of tetrahydropyridines by the diphenylprolinol-catalyzed reaction of $\alpha, \beta$-unsaturated aldehydes with enamides [52] and is in line with Wang's stepwise mechanism with initial formation of 19 [62].

In view of the high nucleophilicities of sulfur ylides [63], we were surprised by MacMillan's statement that iminium ions derived from the imidazolidinones $\mathbf{1 a}$ and $\mathbf{1 b}$ (for structures, see Figure 16) were inert to the ylide 21 [49]. When we combined the pregenerated iminium salts $\mathbf{3 a}-\mathbf{e}$ with the sulfur ylide $\mathbf{2 1}$, the expected cyclopropanes $\mathbf{2 3}$ were indeed formed in good yield, although with low diastereo- and enantioselectivity (Figure 14) [64].

Even the rate constants calculated by Equation 1 agreed, within the general tolerance, with the experimental values; with one exception. The iminium intermediate derived from indole-2carboxylic acid $(\mathbf{3 g})$ reacted at least $10^{5}$ times faster with the 


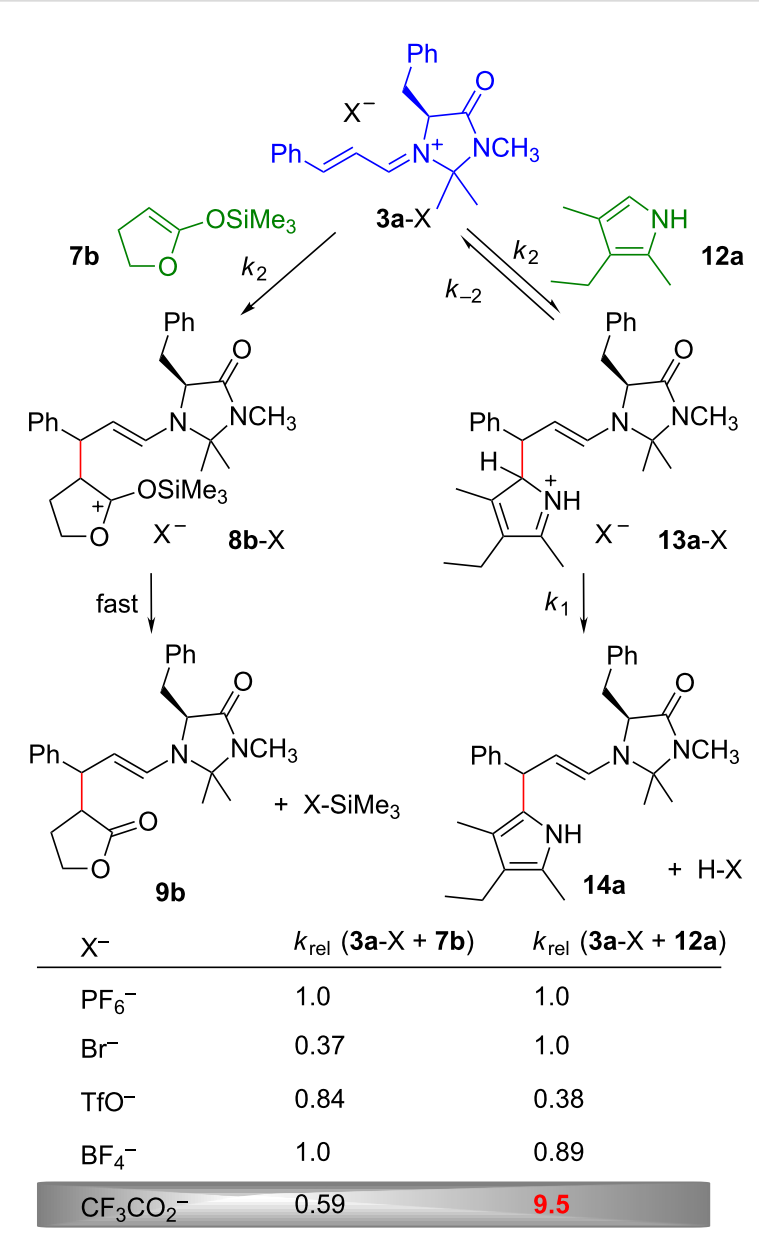

Figure 8: Counterion effects in electrophilic reactions of iminium ions 3a-X (at $20^{\circ} \mathrm{C}$, silyl ketene acetal $7 \mathbf{b}$ in dichloromethane with $c(3 \mathbf{a}$ $\left.\mathrm{CF}_{3} \mathrm{CO}_{2}\right)=(1.7-2.5) \times 10^{-5} \mathrm{M}$, kryptopyrrole $12 \mathrm{a}$ in acetonitrile with $\left.c\left(3 \mathrm{a}-\mathrm{CF}_{3} \mathrm{CO}_{2}\right)=5.0 \times 10^{-5} \mathrm{M}\right)$. sulfur ylide 21 than calculated by Equation 1, which can be explained by electrostatic activation as initially proposed by MacMillan (Figure 15) [49].

Thus, the failure of the imidazolidinones $\mathbf{1 a}$ and $\mathbf{1 b}$ to catalyze cyclopropanations with the sulfur ylide $\mathbf{2 1}$ is not due to the low reactivities of sulfur ylides toward iminium ions, but is due to the high Brønsted basicity of the sulfur ylides $\mathbf{2 4}$, which leads to deprotonation of the imidazolidinium ions $\mathbf{1}-\mathrm{H}^{+}$and inhibition of the formation of the iminium ions 3 (Figure 16) [64].

\section{Enamine activated reactions}

When proline catalysis and related amino-acid catalyzed reactions are excluded, the catalytic cycle depicted in Figure 17 represents the generally accepted mechanism for enamine activated reactions [65-71]. A key-step, not necessarily the ratedetermining step, is the attack of an electrophile 29 at the enamine 28, at the bottom of Figure 17 [72].

In order to calculate the rate constant for this step by Equation 1 one needs the reactivity parameters $N$ and $s_{\mathrm{N}}$ for the enamines $\mathbf{2 8}$ and the electrophilicity parameter $E$ for the electrophiles 29.

The electrophilicity parameters for the Michael acceptors, stabilized carbenium ions, and azodicarboxylates shown in Figure 18 have been derived from the kinetics of their reactions with C-nucleophiles, mostly stabilized carbanions [4,73-80].

As illustrated in Figure 19, the benzhydrylium methodology was again employed for the determination of the nucleophilicities of enamines. Whereas the enamine $\mathbf{3 2} \mathbf{b}$, which is

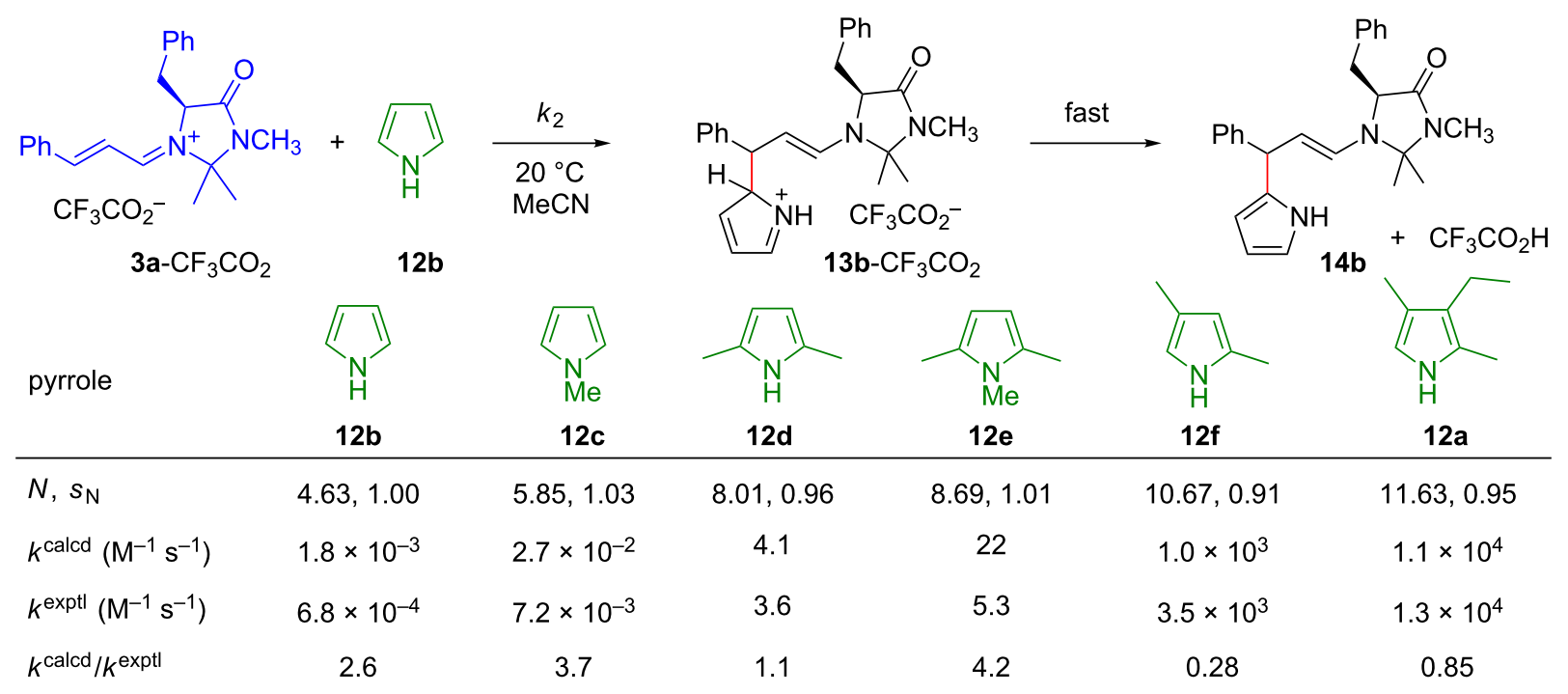

Figure 9: Comparison of calculated and experimental rate constants of electrophilic aromatic substitutions with iminium ions [56]. 


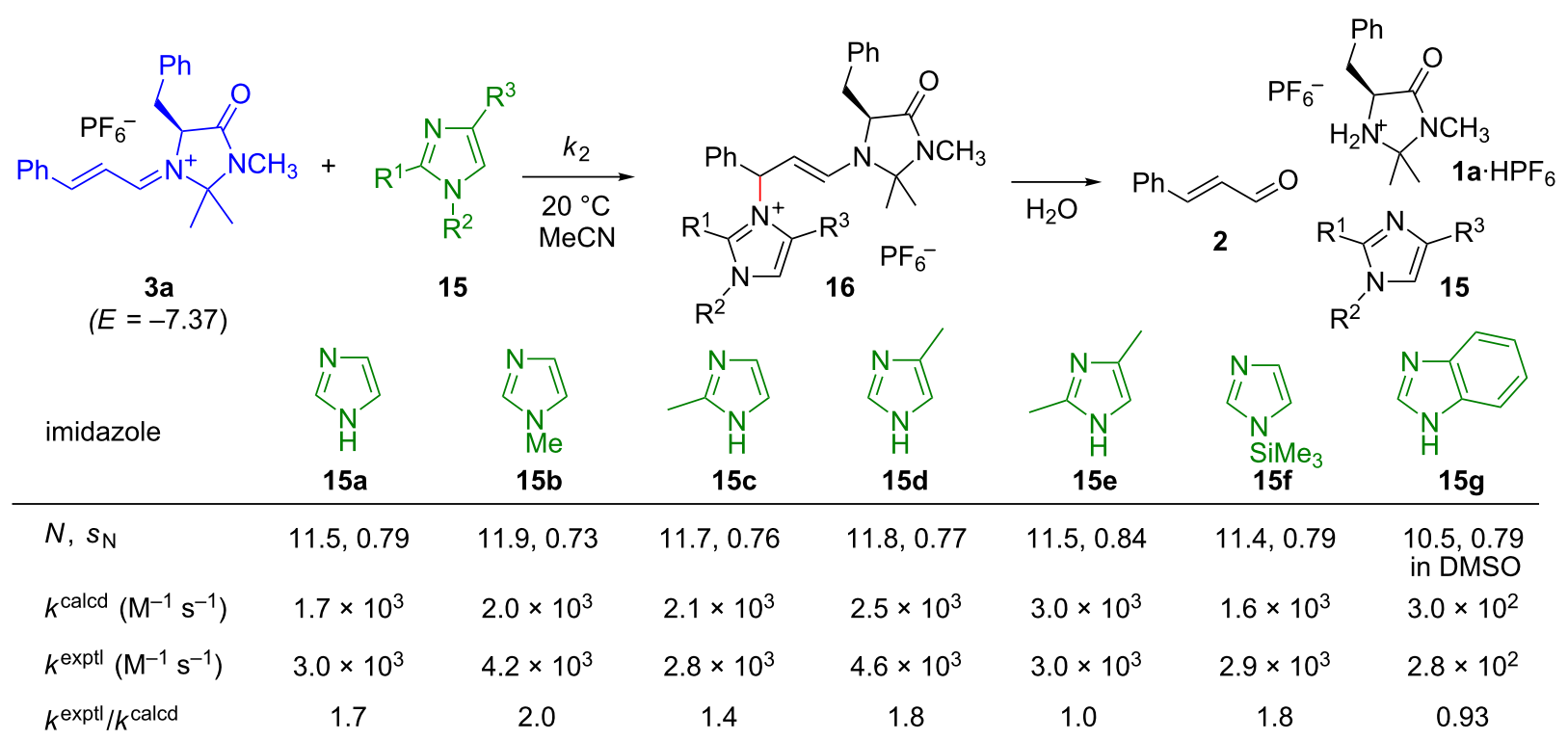

Figure 10: Aza-Michael additions of the imidazoles 15 with the iminium ion 3a [58].

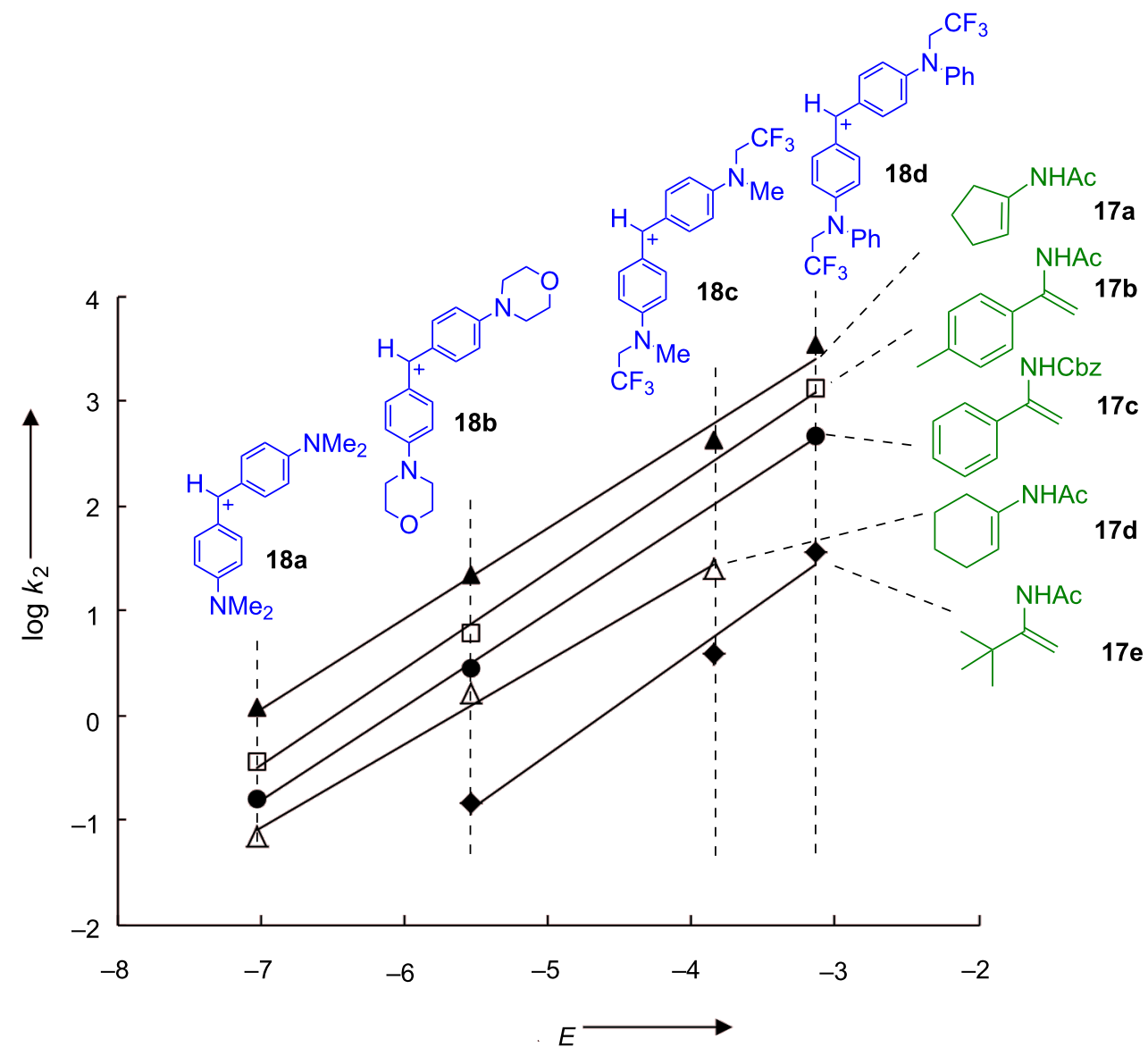

Figure 11: Plots of $\log k_{2}$ for the reactions of enamides $17 \mathrm{a}-17 \mathrm{e}$ with the benzhydrylium ions $18 \mathrm{a}-\mathrm{d}$ in $\mathrm{CH}_{3} \mathrm{CN}$ at $20^{\circ} \mathrm{C}$ versus the electrophilicity parameters $(E)$. 


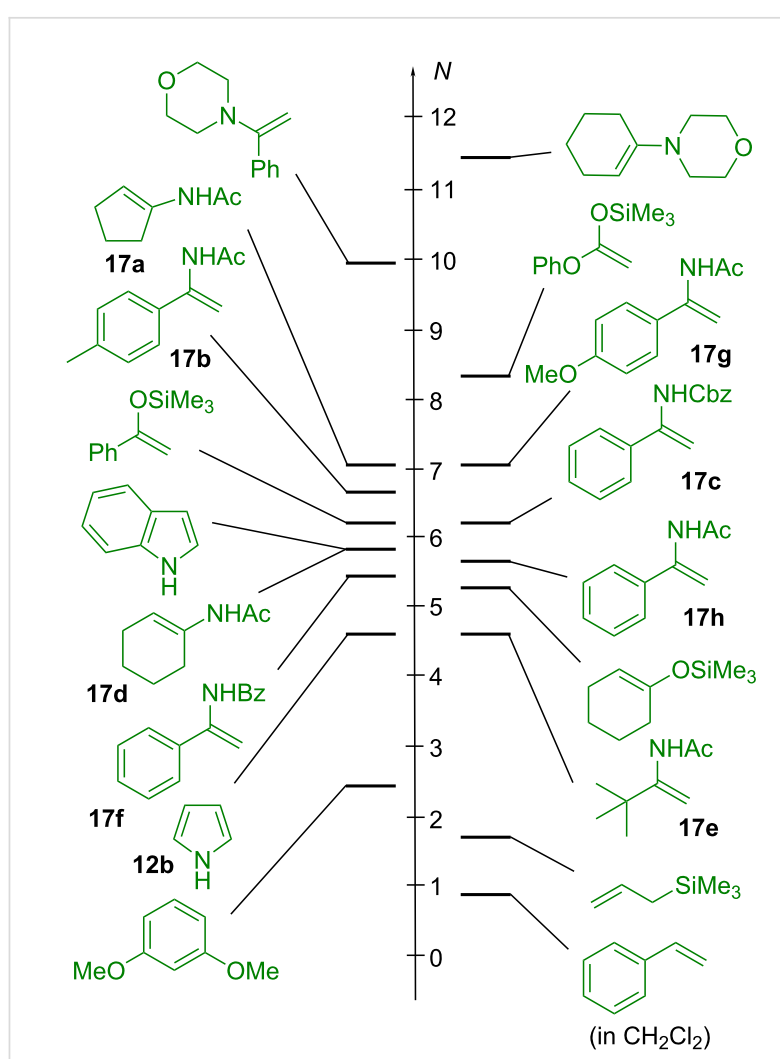

Figure 12: Comparison of the nucleophilicities of enamides 17 with those of several other $\mathrm{C}$ nucleophiles (solvent is $\mathrm{CH}_{3} \mathrm{CN}$ unless otherwise mentioned, $N$ values taken from $[4,61])$. derived from the diphenylprolinol silyl ether [81], had previously been synthesized and characterized (X-ray structure) by Seebach et al. [30], neat samples of the imidazolidinone-derived enamines 32c-32e became only recently available by TsOHcatalyzed condensation of phenylacetaldehyde with the corresponding imidazolidinones and column chromatography on silica gel. The presence of triethylamine $(5 \%)$ in the eluent (ethyl acetate $/ n$-pentane) turned out to be crucial to avoid decomposition of these enamines on the column $[82,83]$.

Kinetic studies of their reactions with benzhydrylium ions 18 of suitable electrophilicity showed that introduction of the $\left(\mathrm{Me}_{3} \mathrm{SiO}\right) \mathrm{Ph}_{2} \mathrm{C}$-group in the 2-position of the pyrrolidine ring of $N$-( $\beta$-styryl)pyrrolidine caused a reduction of reactivity by a factor of 30 to 60 (32a versus $\mathbf{3 2} \mathbf{b})$. A reduction of nucleophilicity by three to five orders of magnitude is encountered for the enamines 32c-32e (Figure 19). The low nucleophilicities of the imidazolidinone derived enamines, which are in line with the larger ${ }^{13} \mathrm{C}$ NMR chemical shifts of $\mathrm{C}-2$ in $\mathbf{3 2 d}$ (101.9 ppm) and 32e (102.9 ppm) compared to that of $\mathrm{C}-2$ in $32 \mathrm{a}$ (97.4 ppm), are not only due to the electron-withdrawing effect of the additional heteroatoms in the heterocyclic rings [83]. An additional factor is shown in Figure 19: While the enamine nitrogen is almost planar in $\mathbf{3 2} \mathbf{b}$, it becomes pyramidalized in the enamines 32c and 32e and thus has a weaker electrondonating effect because of the reduced overlap between the nitrogen lone-pair and the $\pi_{\mathrm{C}-\mathrm{C}}$-bond.

$$
\begin{aligned}
& \mathrm{Ph} \underset{\mathrm{PF}_{6}^{-}}{\stackrel{+}{N} R_{2}}+\int_{\mathrm{Ar}}^{\mathrm{NHAc}} \frac{k_{2}}{k_{-2}} \\
& 3
\end{aligned}
$$$$
17
$$<smiles>[R20]N/C=C\C(CC([Al])=NC(=O)O)c1ccccc1</smiles>

19

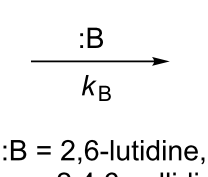
2,4,6-collidine<smiles>[R20]N/C=C\C(/C=C(/[Ga])NC(=O)[OH2+])c1ccccc1</smiles>

\begin{tabular}{|c|c|c|c|c|}
\hline enamide & $\begin{array}{c}17 \mathbf{b} \\
\left(\mathrm{Ar}=4-\mathrm{Me}-\mathrm{C}_{6} \mathrm{H}_{4^{-}}\right)\end{array}$ & $\begin{array}{c}17 \mathrm{~g} \\
\left(\mathrm{Ar}=4-\mathrm{OMe}-\mathrm{C}_{6} \mathrm{H}_{4^{-}}\right)\end{array}$ & $\begin{array}{c}17 \mathbf{b} \\
\left(\mathrm{Ar}=4-\mathrm{Me}-\mathrm{C}_{6} \mathrm{H}_{4^{-}}\right)\end{array}$ & $\begin{array}{c}17 \mathrm{~g} \\
\left(\mathrm{Ar}=4-\mathrm{OMe}-\mathrm{C}_{6} \mathrm{H}_{4^{-}}\right)\end{array}$ \\
\hline$N, s_{N}$ & $6.57,0.91$ & $7.06,0.85$ & $6.57,0.91$ & $7.06,0.85$ \\
\hline$k^{\text {calcd }}\left(\mathrm{M}^{-1} \mathrm{~s}^{-1}\right)$ & 0.19 & 0.55 & 9.0 & 20 \\
\hline$k^{\text {exptl }}\left(\mathrm{M}^{-1} \mathrm{~s}^{-1}\right)$ & 0.26 & 0.73 & 3.3 & 7.1 \\
\hline$k^{\text {exptl }} / k^{\text {calcd }}$ & 1.4 & 1.3 & 0.36 & 0.35 \\
\hline
\end{tabular}<smiles></smiles>

Figure 13: Experimental and calculated rate constants $k_{2}$ for the reactions of $17 \mathbf{b}$ and $\mathbf{1 7 g}$ with $\mathbf{3 a}$ and $\mathbf{3} \mathbf{b}$ in the presence of $2,6-\mathrm{lutidine}$ in $\mathrm{CH}_{2} \mathrm{Cl}_{2}$ at $20^{\circ} \mathrm{C}[61]$. 


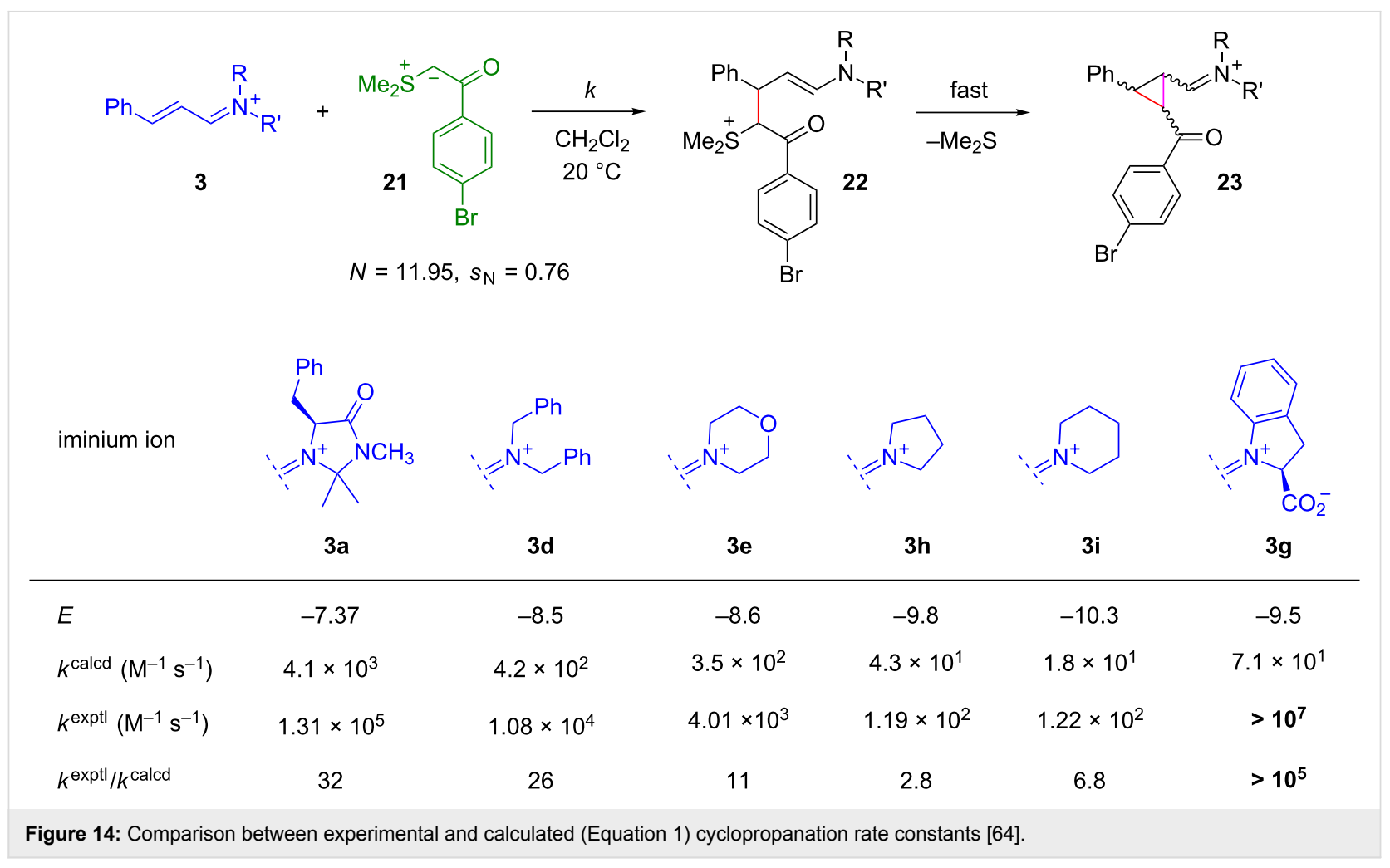

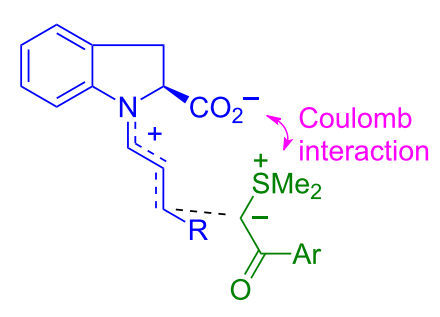

Figure 15: Electrostatic activation of iminium activated cyclopropanations with sulfur ylides.

Combination of the data in Figure 18 and Figure 19 now explains why the Jørgensen-Hayashi diphenylprolinol trimethylsilyl ether [81], the precursor of $\mathbf{3 2} \mathbf{b}$, and structurally related pyrrolidines have previously been employed for catalyzing the reactions of aldehydes and ketones with weak electrophiles, such as $\beta$-nitrostyrene $(E=-13.9)$ [85] or di-tertbutyl azodicarboxylate $(E=-12.2)$ [86]. The less basic imidazolidinones, which yield the less nucleophilic enamines $\mathbf{3 2 d}$ and 32e, are suitable catalysts for reactions with stronger electrophiles, such as the chlorinating agent 2,3,4,5,6,6-hexachlorocyclohexan-2,4-dien-1-one $(E=-6.75)$ [87] and, in particular, stabilized carbocations, which are generated in situ from the corresponding alcohols under weakly acidic conditions $[14,88,89]$. Suggestions for further promising electrophilic reaction partners in enamine activated reactions [90] can be derived from the electrophilicity scales in [4].
When proline or structurally related bifunctional catalysts are employed, the mechanism depicted in Figure 17 has to be modified. List and Houk explained the high enantioselectivity of proline catalyzed reactions of aldehydes or ketones with electrophiles by the transition state TS-A in Figure 20, in which the electrophile is activated by the proton of the carboxy group [71]. The formation of oxazolidinones, the only observable intermediates of this reaction cascade, was considered to be an unproductive dead end [70]. On the other hand, Seebach and Eschenmoser raised the question of whether oxazolidinones, rather than being "parasitic species", may also play a decisive role in determining the stereochemical course of prolinecatalyzed reactions. In order to account for the observed stereoselectivities, it was suggested that TS-B is favored over the stereoelectronically preferred $\mathbf{T S}-\mathbf{C}$, because it yields the more stable oxazolidinone [91].

Figure 21 shows that the enaminocarboxylate $3^{-}$reacts 50 to 60 times faster with benzhydrylium ions than pyrrolidinocyclohexene $\mathbf{3 6}$ and even 800 to 900 times faster than the methyl ester 37 [92].

We consider the high rates of the reactions of $\mathbf{3 3}^{-}$with benzhydrylium ions $\mathbf{1 8}$ as evidence for anchimeric assistance by the carboxylate group. As only part of the accelerating effect of the $\mathrm{CO}_{2}{ }^{-}$group can be due to Coulomb attraction, the formation of the $\mathrm{C}-\mathrm{O}$ bond of the oxazolidone $\mathbf{3 4}$ is concluded to 


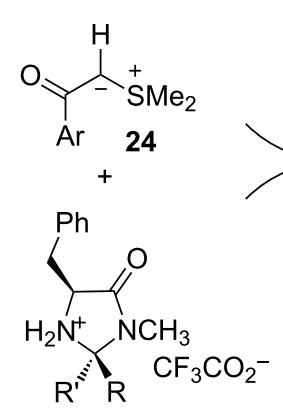

$1 \mathrm{a}, \mathrm{b}-\mathrm{H}^{+}$<smiles>CC(=O)C(C)C(N)=O</smiles>

$\mathrm{Ph}$

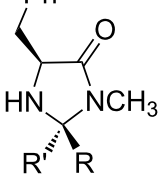

$\mathrm{R}=\mathrm{R}^{\prime}=\mathrm{CH}_{3} ; \mathbf{1} \mathbf{a}$

$\mathrm{R}=t-\mathrm{Bu}, \mathrm{R}^{\prime}=\mathrm{H} ; \mathbf{1} \mathbf{b}$
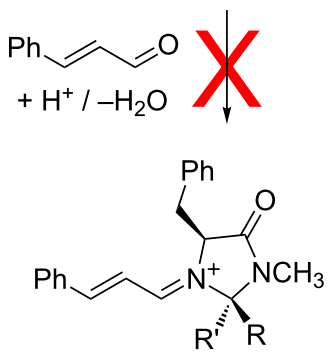

3a, $3 \mathbf{b}$

Figure 16: Sulfur ylides inhibit the formation of iminium ions.

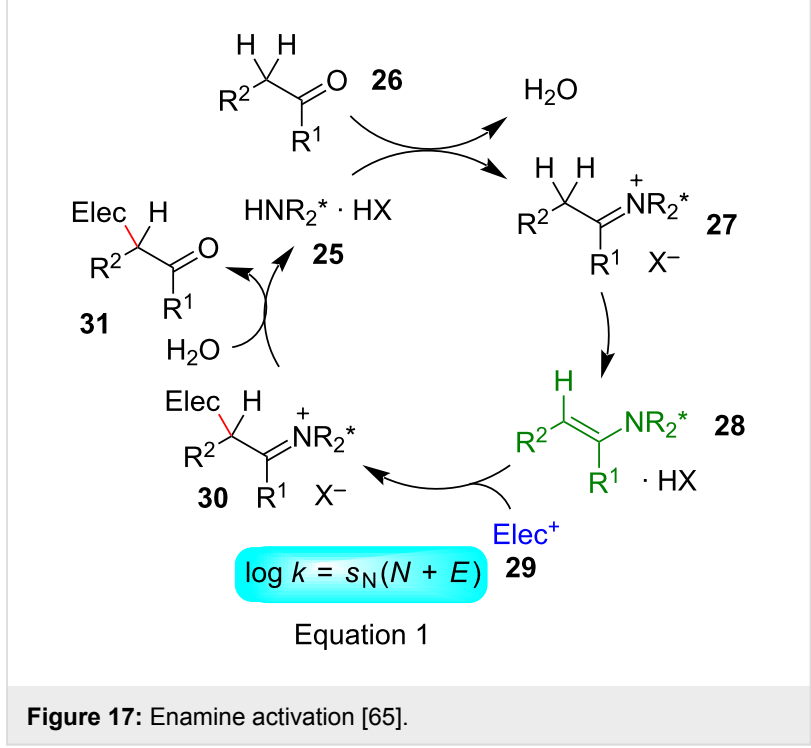

occur concomitantly with the formation of the $\mathrm{C}-\mathrm{C}$ bond. The observation that $\beta$-nitrostyrene, a neutral electrophile, also reacts $10^{2}$ times faster with $\mathbf{3 3}^{-}$than with $\mathbf{3 6}$ also excludes Coulomb attraction to be the major factor for the high reactivity of $\mathbf{3 3}^{-}$. On the other hand, di-tert-butyl azodicarboxylate

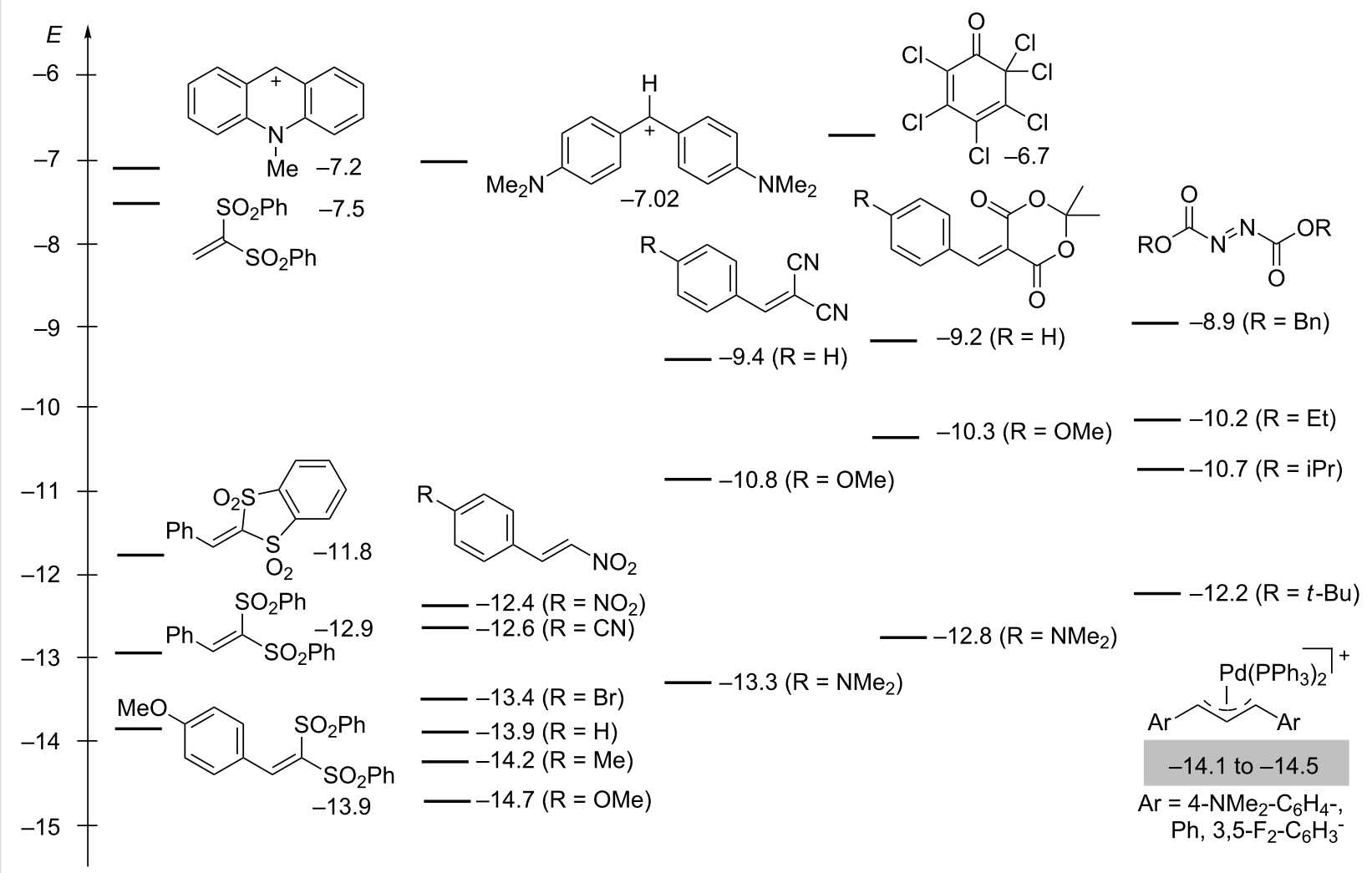

Figure 18: Electrophilicity parameters $E$ for classes of compounds that have been used as electrophilic substrates in enamine activated reactions $[4,73-80]$. 


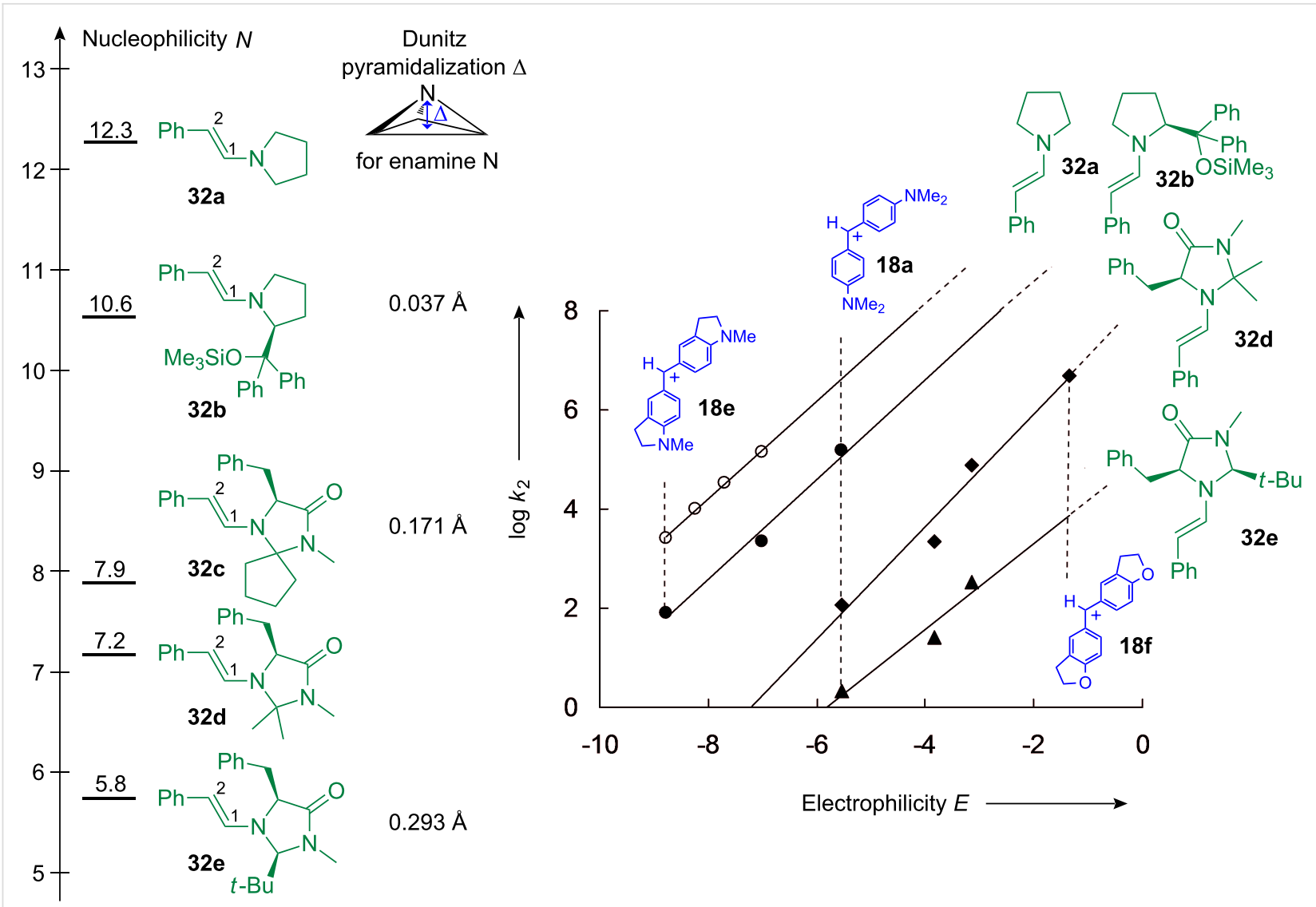

Figure 19: Quantification of the nucleophilic reactivities of the enamines $32 \mathrm{a}-\mathbf{e}$ in acetonitrile $\left(20^{\circ} \mathrm{C}\right)$ [83]; a definition of the Dunitz pyramidalization $\Delta$ is given in [84].

$$
\overbrace{R^{\prime}}
$$

TS-A

(s-trans) List \& Houk

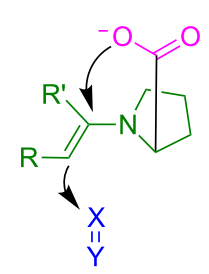

TS-B

(s-cis) oxazolidinone mech

Figure 20: Proposed transition states for the stereogenic step in proline-catalyzed reactions.

reacts only six times faster with $\mathbf{3 3}^{-}$than with $\mathbf{3 6}$, showing that the magnitude of the anchimeric assistance depends largely on the nature of the electrophile.

The data in Figure 21 thus suggest that the oxazolidinones 34 are formed in the stereodifferentiating step when enaminecarboxylate anions are the effective nucleophiles. However, our observations do not affect the rationalization of the stereo- selectivities of proline-catalyzed reactions by TS-A when the electrophilic attack occurs at an enaminocarboxylic acid. Blackmond's observation of a change of enantioselectivity by added bases is in line with our interpretations [93].

\section{Quantitative aspects of N-heterocyclic carbene $(\mathrm{NHC})$ catalysis}

As the following discussion will focus on the difference between the kinetic term "nucleophilicity" and the thermodynamic term "Lewis basicity", let us first illustrate this aspect by comparing the behavior of two well-known organocatalysts, 1,4-diazabicyclo[2.2.2] octane (DABCO, 38) and (4-dimethylamino)pyridine (DMAP, 39). As shown in Figure 22, DABCO (38) reacts approximately $10^{3}$ times faster with benzhydrylium ions than DMAP (39), i.e., DABCO (38) is considerably more nucleophilic than DMAP (39) [94].

On the other hand, the equilibrium constant for the formation of the Lewis acid-Lewis base adduct with $\mathbf{1 8 g}$ is 160 times smaller for DABCO (38) than for DMAP (39), i.e., DABCO (38) is a significantly weaker Lewis base than DMAP (39). We have previously discussed that it is the higher reorganization energy 

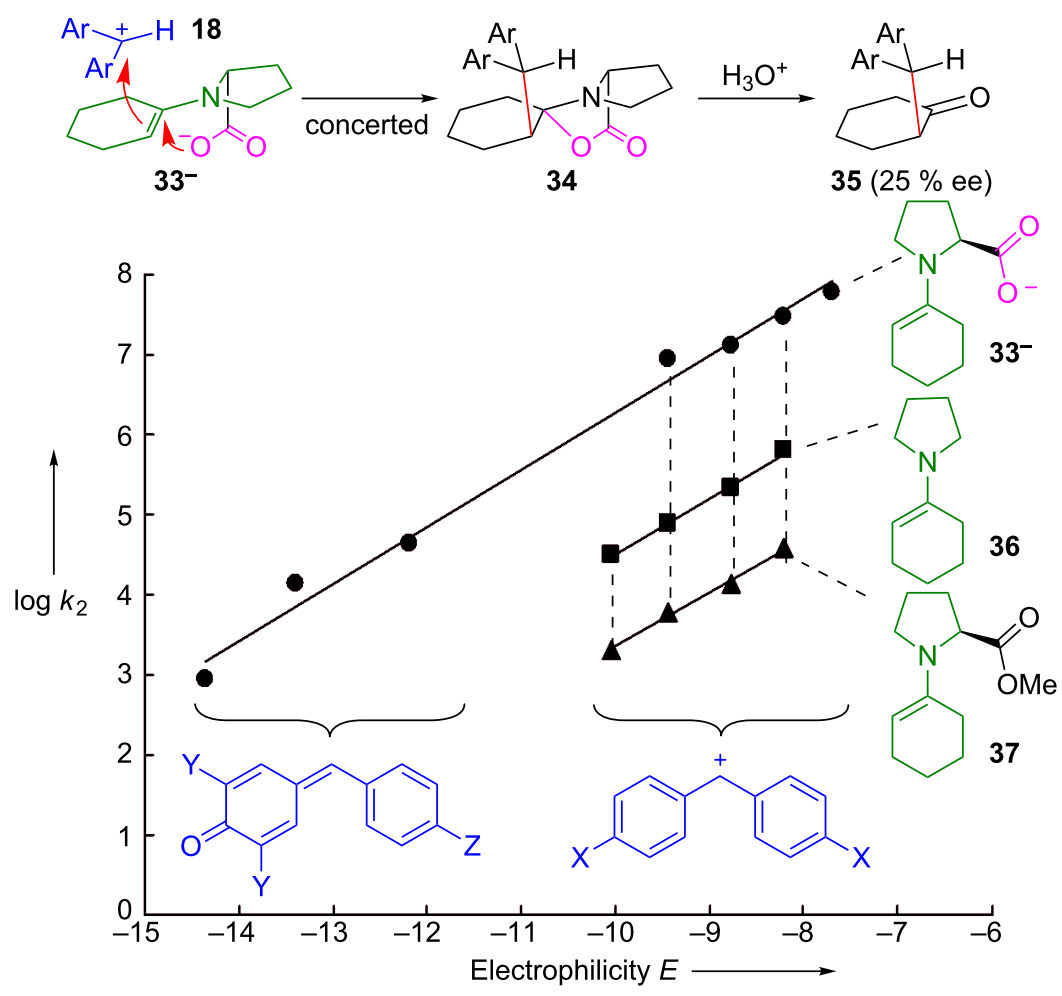

Figure 21: Kinetic evidence for the anchimeric assistance of the electrophilic attack by the carboxylate group. The hydrolysis product $(R)-35$ was

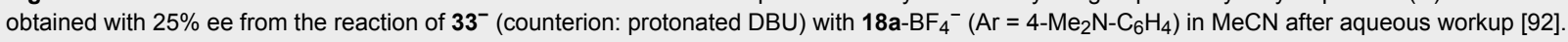
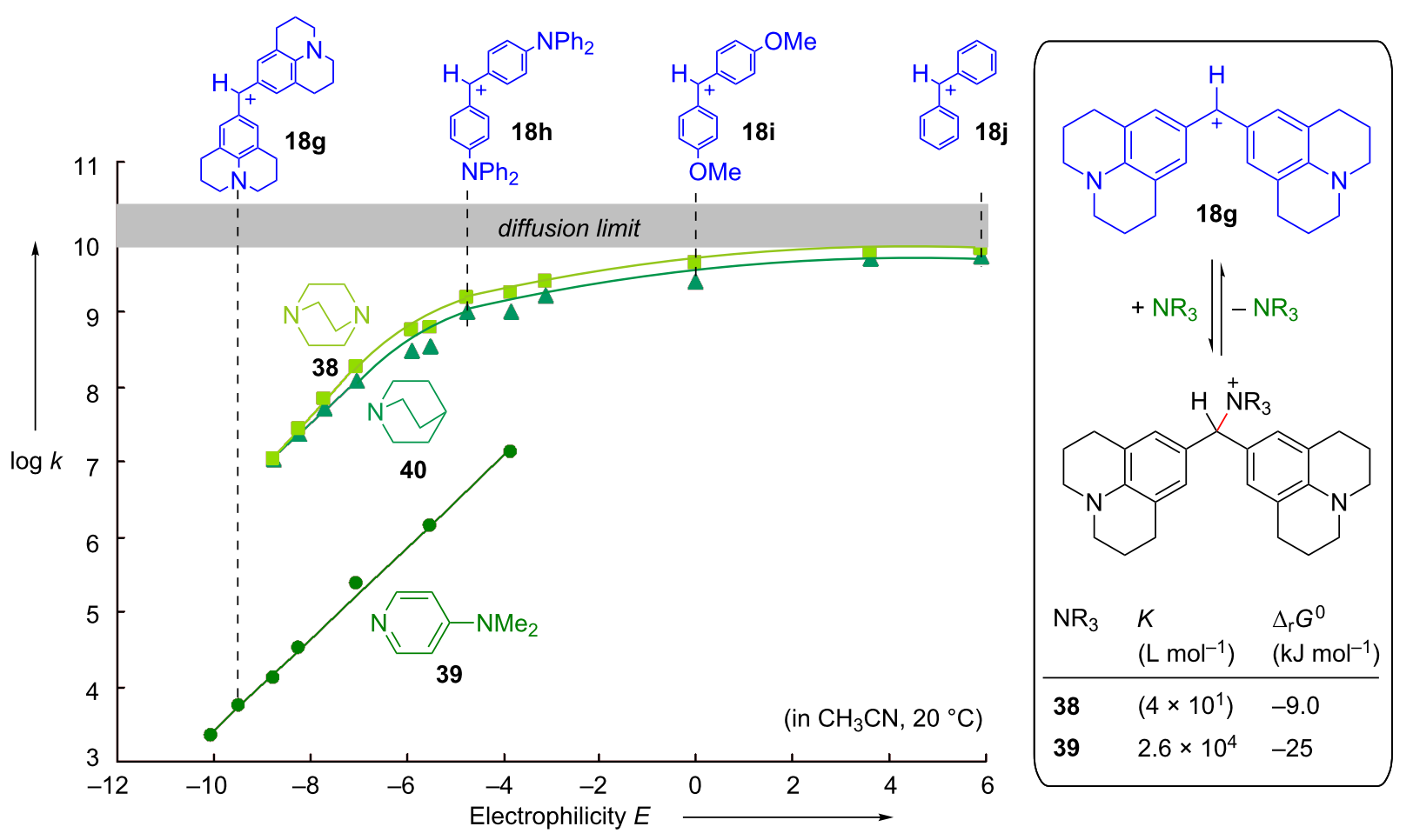

Figure 22: Differentiation of nucleophilicity and Lewis basicity (in acetonitrile at $20^{\circ} \mathrm{C}$ ): Rate (left) and equilibrium constants (right) for the reactions of amines with benzhydrylium ions [94,95]. 
for the reaction of DMAP (39) that is responsible for the higher intrinsic barrier and subsequently the lower nucleophilicity of DMAP (39) [94].

The upper part of Figure 23 compares the relative rates for the reactions of various organocatalysts (in THF) with the benzhydrylium ion $\mathbf{1 8 e}$ and the structurally related quinone methide 18k. This comparison reveals that the nucleophilicities of the NHCs 41-43 do not differ fundamentally from those of other organocatalysts, e.g., triphenylphosphine (10b), DMAP (39), and DABCO (38) [96].

The considerably lower nucleophilicity of the triazolylidene $\mathbf{4 3}$ compared with the imidazolylidene $\mathbf{4 2}$ can be explained by the inductive electron withdrawal of the extra nitrogen in the triazol derivative 43. The similar nucleophilicities of the imidazoleand imidazolidine-derived carbenes $\mathbf{4 2}$ and $\mathbf{4 1}$ are, at first glance, surprising and will be discussed below. The lower part of Figure 23 illustrates that all three NHCs, 41, 42, and 43, react quantitatively with the quinone methide $\mathbf{1 8 k}$, while none of the other Lewis bases, despite their similar nucleophilicities, gives an adduct. The resulting conclusion, that all NHCs are significantly stronger Lewis bases than $\mathrm{PPh}_{3}$ (10b), DMAP (39), and DABCO (38), is confirmed by quantum chemical calculations: The methyl cation affinities (MCAs) of the three carbenes 41-43 are 100-200 $\mathrm{kJ} \mathrm{mol}^{-1}$ higher than those of the other Lewis bases in Figure 23 [96].

As the carbenes $\mathbf{4 1}$ and $\mathbf{4 2}$ have almost identical nucleophilicities and Lewis basicities, the question arose as to why imidazolidine-2-ylidenes (for example, 41) have rarely been used as organocatalysts, while unsaturated NHCs (for example, 42) have been reported to catalyze a large variety of reactions [97-104]. Can the difference be explained by the properties of the Breslow intermediates [105]? To address this question, the deoxy Breslow intermediates 45 [106-108] were synthesized by

\section{Kinetics: Nucleophilicities}<smiles>[X]c1ccc([C+]c2ccc([Y])cc2[CH+]c2ccc([X])cc2)cc1</smiles>

$\mathrm{Nu}=$

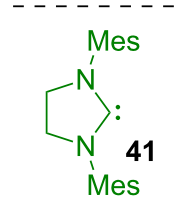

$k_{\text {rel }}$ (reaction with $\mathbf{1 8 k}$ )

$k_{\text {rel }}$ (reaction with $18 \mathrm{e}$ )

2500

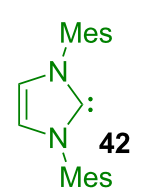<smiles>Pc1cccnc1</smiles>

1100

\section{0} 0.068<smiles>CN(C)c1ccncc1</smiles><smiles>C1CN2CCN1CC2</smiles>
38 530

\section{Thermodynamics: Lewis basicities}<smiles>COc1c(-c2ccccc2)cc(C([NH3+])c2ccc(N(C)C)cc2)cc1-c1ccccc1</smiles>

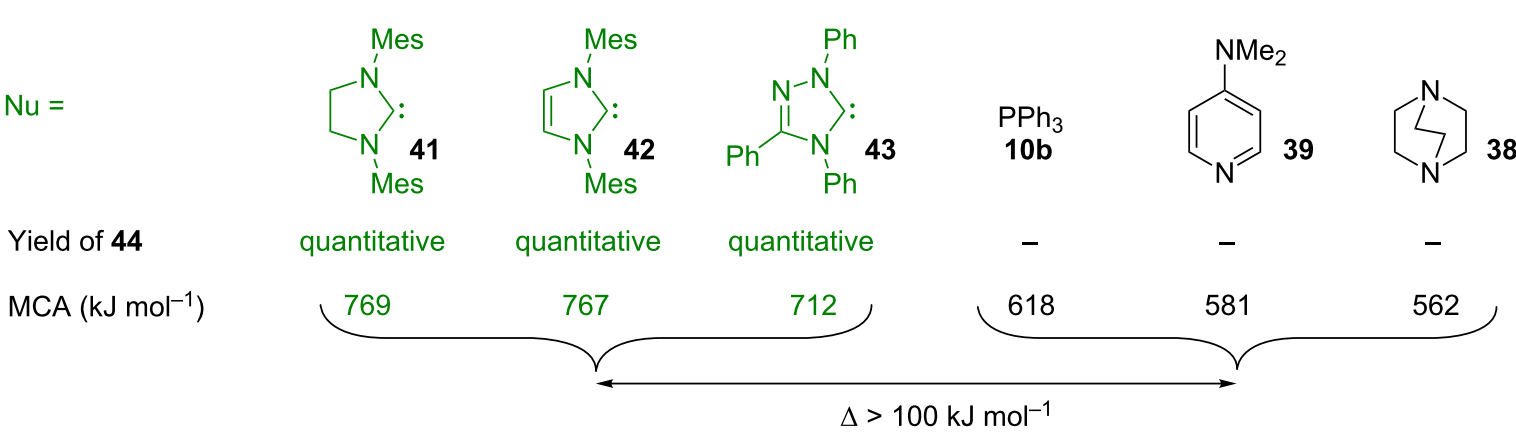

Figure 23: NHCs $\mathbf{4 1}, \mathbf{4 2}$, and $\mathbf{4 3}$ are moderately active nucleophiles and exceptionally strong Lewis bases (methyl cation affinity, MCA, was calculated for the reaction $\mathrm{CH}_{3}{ }^{+}+\mathrm{Nu} \rightarrow \mathrm{CH}_{3}-\mathrm{Nu}^{+}$on $\mathrm{MP2} / 6-31+\mathrm{G}(\mathrm{d}, \mathrm{p}) / / \mathrm{B} 98 / 6-31 \mathrm{G}(\mathrm{d})$ level of theory) [96]. 
reactions of the NHCs 41-43 with benzyl bromides and subsequent deprotonation of the resulting amidinium ions.

The linear correlations in Figure 24 show that the nucleophilic reactivities of the so-called deoxy Breslow intermediates 45a-f can be described by Equation 1 [107]. In contrast to the situation described for the NHCs in Figure 23, the benzylideneimidazolines $45 \mathbf{a}, \mathbf{d}$ are now $10^{3}$ times more nucleophilic than the corresponding benzylidene-imidazolidines $4 \mathbf{4 c}, \mathbf{f}$ (Figure 24 and Figure 25a).

The different behavior was analyzed by quantum chemical calculations (Figure 25b). In the same way that the nucleophilicity order of the carbenes $(\mathbf{4 1} \approx \mathbf{4 2}>\mathbf{4 3}$, Figure 23$)$ parallels the order of the Lewis basicities (methyl cation affinities) of the model compounds $(49 \mathrm{c} \approx 49 \mathrm{a}>49 \mathrm{~b}$, Figure $25 \mathrm{~b}$ bottom), the nucleophilicity order of the deoxy Breslow intermediates $(45 a>45 b>45 c$, Figure 25a) also mirrors the order of the proton affinities of the model compounds $(47 a>47 b>47 c$, Figure 25b, top) [107].
A rationalization for the different sequence in the two series can be derived from the nucleus-independent chemical shifts (NICS) [109-111], which are considered to be a measure of aromaticity. In agreement with the almost equal lengths of the exocyclic $\mathrm{C}-\mathrm{C}$ bonds in $45 \mathrm{a}(136.1 \mathrm{pm})$ and 45c (135.4 pm), as determined by X-ray crystallography, none of the two heterocyclic rings in $47 \mathrm{a}$ and $47 \mathrm{c}$ shows aromatic character (NICS(1)). However, while the electrophilic addition to the exocyclic double bond of 47 a yields the cyclic conjugated $6 \pi$ system in $\mathbf{4 8 a}$, the analogous electrophilic addition to $47 \mathrm{c}$ yields the nonaromatic amidinium ion $\mathbf{4 8 c}$. The high nucleophilicity of $\mathbf{4 5 a}$, which is mirrored by the high proton affinity of $\mathbf{4 7 a}$, can thus be explained by the gain of aromaticity during electrophilic attack. The same line of arguments can be used to rationalize the higher nucleophilicities and basicities of the triazoline derivatives $\mathbf{4 5 b}$ and $\mathbf{4 7 b}$, respectively [107].

As the unsaturated carbenes $49 \mathrm{a}$ and $49 \mathrm{~b}$ have already a similar aromatic character as the azolium ions $\mathbf{4 8 a}$ and $\mathbf{4 8 b}$ generated

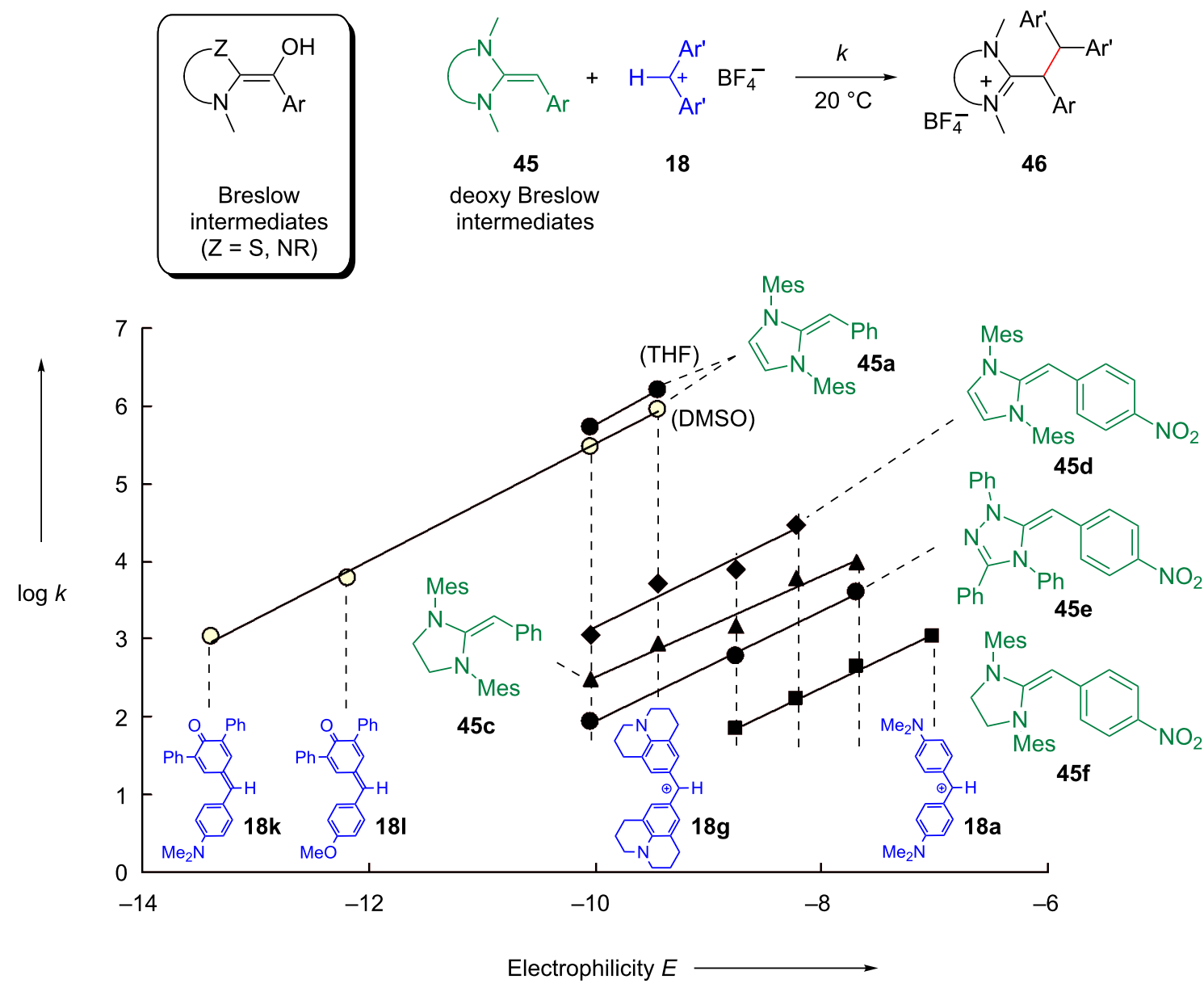

Figure 24: Nucleophilic reactivities of the deoxy Breslow intermediates 45 in THF at $20^{\circ} \mathrm{C}$ [107] 
a)

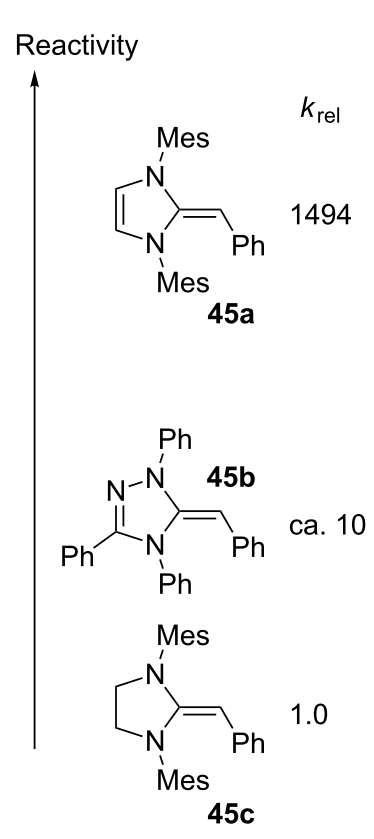

b)

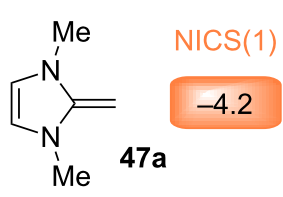

$\Delta H^{\circ}=-P A$

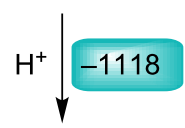<smiles>CCCCCn1ccn(C)[c+]1C</smiles>

$\Delta H^{\circ}=-\mathrm{MCA}$<smiles>C[13CH]1CC[13CH]1</smiles><smiles>CN1C=CN(C)C1</smiles>

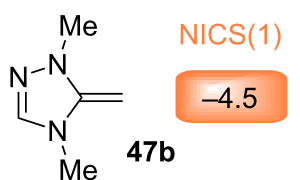<smiles>C=C1N(C)CCN1C=[Ge]</smiles><smiles>CC(C)[OH2+]</smiles><smiles>CC(C)=[13CH]</smiles><smiles>C[c+]1[c+](C)n(C)ncn1C</smiles><smiles>C[C+]1N(C)CCN1C</smiles><smiles></smiles><smiles>C[C@@H]1C[C@@H]2CC[C@@H]1C2</smiles>

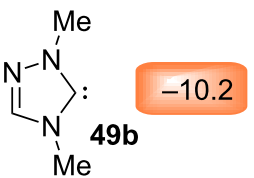<smiles>CN1CCN(C)C1</smiles>

Figure 25: Comparison of the proton affinities (PA, from [107]) of the diaminoethylenes 47a-c with the methyl cation affinities (MCA, from [96]) of the corresponding carbenes $49 \mathrm{a}-\mathrm{c}$ (in kJ mol${ }^{-1}, \mathrm{MP} 2 / 6-31+\mathrm{G}(2 \mathrm{~d}, \mathrm{p}) / / \mathrm{B} 98 / 6-31 \mathrm{G}(\mathrm{d})$ ), and the NICS(1) values of 47-49 (B3LYP/6-311+G(d)) (from [107])

by protonation, unsaturated carbenes neither show higher basicity nor higher nucleophilicity than their saturated analogues [107].

Are the properties of the deoxy Breslow intermediates also representative for the real Breslow intermediates? As shown by Berkessel and co-workers [112], Breslow intermediates generally exist as the keto tautomers $\mathbf{5 1}$, and attempts to generate their O-silylated derivatives $\mathbf{5 2}$ have failed (Figure 26).

In order to get closer to the actual Breslow intermediates than in Rovis' aza-Breslow intermediates [113], we synthesized and isolated the O-methylated Breslow intermediates 55a-c, 57, and 59 as described in Figure 27 [114]. Some of them were characterized by single-crystal X-ray crystallography.

Kinetic studies of their reactions with benzhydrylium ions provided their reactivity parameters $N$ and $s_{\mathrm{N}}$ [114], and Figure 28 compares the relative reactivities of O-methylated and deoxy-Breslow intermediates toward the bis-pyrrolidinosubstituted benzhydrylium ion 181. Comparison of the left and the central column shows that the O-methylated Breslow intermediates $\mathbf{5 5 b}$ and $\mathbf{5 9}$ are $10^{2}$ times less reactive than their deoxy analogues 61 and $\mathbf{4 5 b}$, respectively. Obviously, the transition state is more affected by the destabilization of the cationic adduct due to the inductive electron-withdrawing effect than by<smiles>Pc1ccccc1</smiles><smiles>CCC(=O)O</smiles>

43<smiles>CCC(=O)C1N(c2ccccc2)N=C(c2ccccc2)N1c1ccccc1</smiles>

51<smiles>CC/C(OC)=C1\N(c2ccccc2)N=C(c2ccccc2)N1c1ccccc1</smiles>

52
Figure 26: Berkessel's synthesis of a Breslow intermediate (51, keto tautomer) from carbene 43 [112].

the + M-effect of the methoxy group, which raises the HOMO of the reactants. Replacement of the sulfur atom in the benzothiazole by a $\mathrm{NCH}_{3}$ group $(\mathbf{5 5 b} \rightarrow \mathbf{5 5 c})$ shows that imidazole derivatives are approximately four orders of magnitude more reactive than structurally analogous thiazole derivatives, which can, again, be assigned to the different electronegativities of sulfur and nitrogen. 


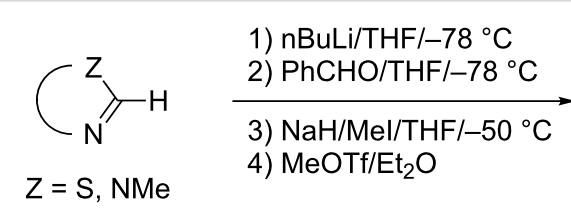

53

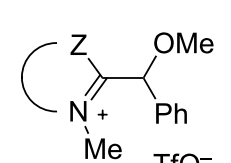

54

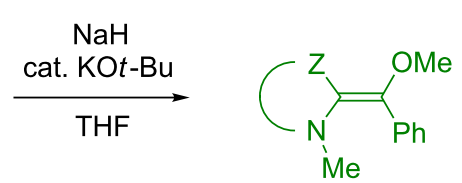

55<smiles>COC(=C1SC(C)=C(C)N1C)c1ccccc1</smiles>

$55 a$<smiles>COC(=C1Sc2ccccc2N1C)c1ccccc1</smiles>

$55 \mathrm{~b}$<smiles>COC(=C1N(C)c2ccccc2N1C)c1ccccc1</smiles>

55c

$(82 \%,(Z):(E)=2: 1)$

$(87 \%,(Z):(E)=2: 1)$<smiles>CN(C)S(=O)(=O)N1C=CN(c2ccccc2)CN1C1=NN(c2ccccc2)CN1C1=Cc2ccccc21</smiles>

43
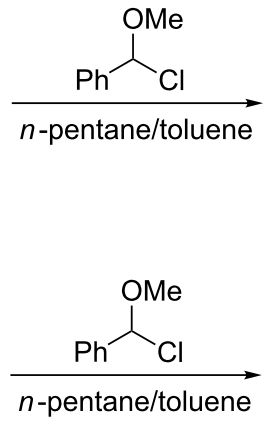<smiles>COC(c1ccccc1)c1n(C)cc[n+]1C</smiles>

56

$(79 \%)$<smiles>COC(c1ccccc1)c1n(-c2ccccc2)nc(-c2ccccc2)[n+]1-c1ccccc1</smiles>

58

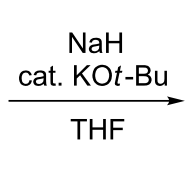<smiles>COC(=C1N(c2ccccc2)N=C(c2ccccc2)N1c1ccccc1)c1ccccc1</smiles>

59<smiles>COC(=C1N(C)C=CN1S(C)(=O)=O)c1ccccc1</smiles>

57

(57\%)
Figure 27: Synthesis of O-methylated Breslow intermediates [114].

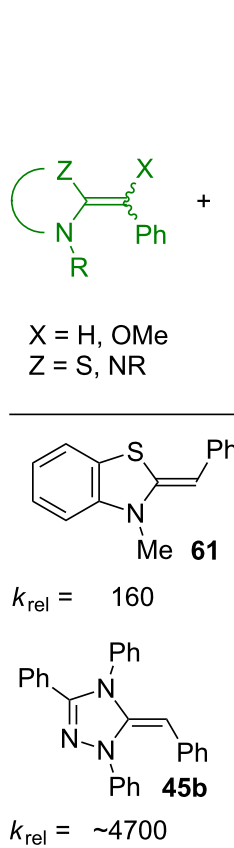

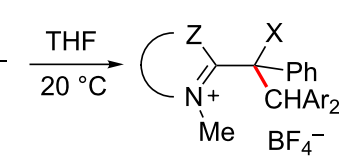

60

Ar $=4$-pyrrolidinophenyl
Figure 28: Relative reactivities of deoxy- and O-methylated Breslow intermediates [114].

\section{Conclusion}

Organocatalytic reactions are complex multicomponent reactions, and a detailed description of the kinetics of the complete catalytic cycles is not yet possible. We have demonstrated, however, that important information can be obtained by specifically synthesizing relevant intermediates and studying the kinetics of their reactions with nucleophiles or electrophiles. By including them in our comprehensive electrophilicity and nucleophilicity scales (Figure 29), it has become possible to settle mechanistic controversies and to explore the scope of substrates suitable for iminium as well as for enamine activated reactions.

Rate and equilibrium studies of the reactions of N-heterocyclic carbenes and the corresponding deoxy Breslow intermediates showed that N-heterocyclic carbenes have similar nucleophilicities as other frequently employed organocatalysts, but are much stronger Lewis bases. The $10^{3}$ times higher nucleophilicities of benzylidene-imidazolines compared with benzylidene-imidazolidines explain why imidazol-2-ylidenes but not imidazolidine-2-ylidenes are commonly used organocatalysts. 
Nucleophilicity $N / s_{\mathrm{N}}$

in dichloromethane if not mentioned otherwise $\log k=s_{N}(N+E)$ Equation (1)

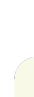

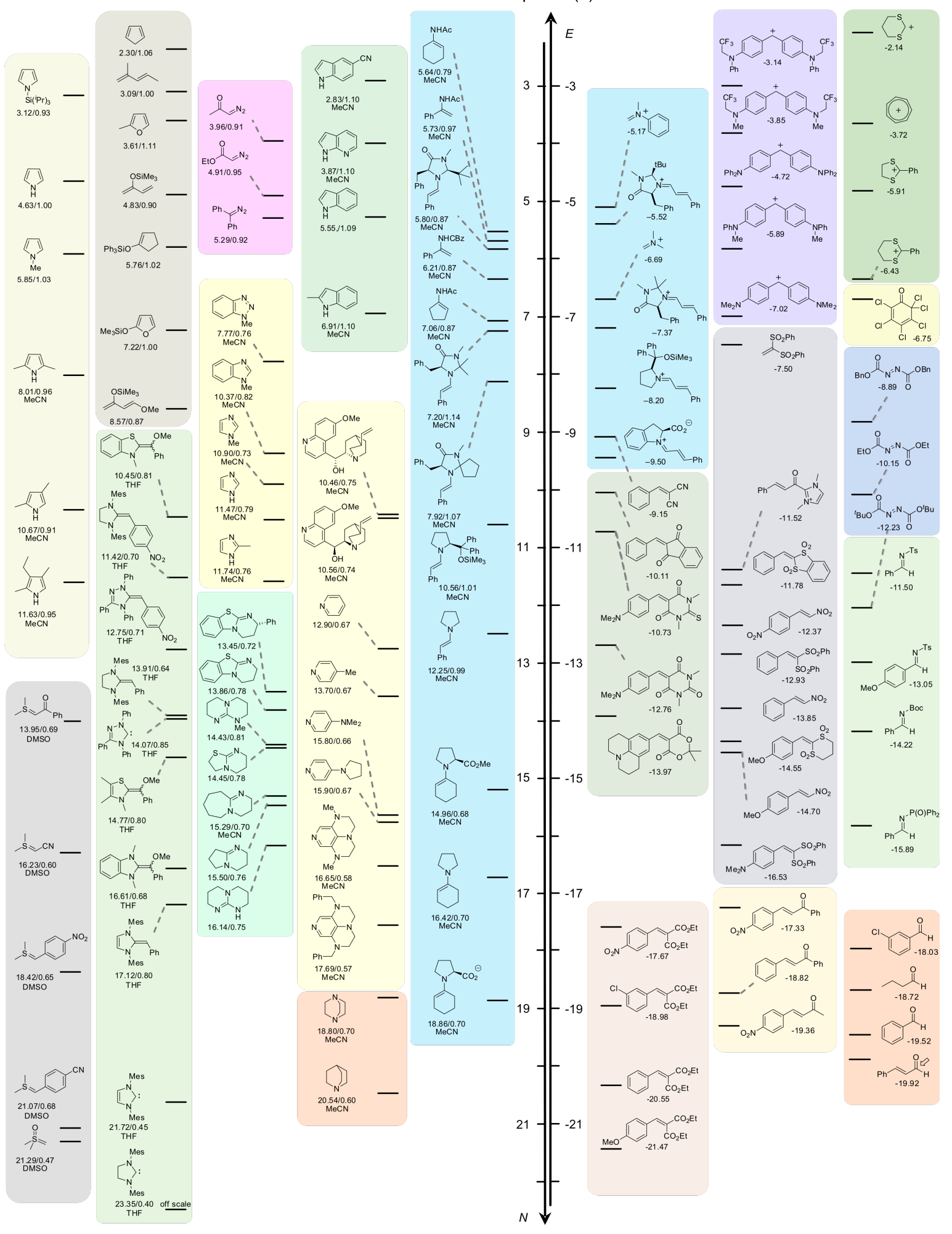

Electrophilicity $E$

$$
20
$$




\section{Acknowledgements}

We thank the Deutsche Forschungsgemeinschaft (Schwerpunktprogramm 1179 Organokatalyse / Priority Program 1179 Organocatalysis 2004-2010 and SFB 749) for financial support.

\section{References}

1. Mayr, H.; Patz, M. Angew. Chem., Int. Ed. Engl. 1994, 33, 938-957. doi:10.1002/anie.199409381

2. Mayr, H.; Bug, T.; Gotta, M. F.; Hering, N.; Irrgang, B.; Janker, B.; Kempf, B.; Loos, R.; Ofial, A. R.; Remennikov, G.; Schimmel, H. J. Am. Chem. Soc. 2001, 123, 9500-9512. doi:10.1021/ja010890y

3. Mayr, H.; Ofial, A. R. J. Phys. Org. Chem. 2008, 21, 584-595. doi:10.1002/poc.1325

4. For a comprehensive database of nucleophilicity parameters $N$ and $s_{N}$ as well as electrophilicity parameters $E$, see http://www.cup.uni-muenchen.de/oc/mayr/DBintro.html.

5. Mayr, H. Angew. Chem., Int. Ed. 2011, 50, 3612-3618. doi:10.1002/anie.201007923

6. Boess, E.; Schmitz, C.; Klussmann, M. J. Am. Chem. Soc. 2012, 134, 5317-5325. doi:10.1021/ja211697s

7. Horn, M.; Mayr, H.; Lacôte, E.; Merling, E.; Deaner, J.; Wells, S.; McFadden, T.; Curran, D. P. Org. Lett. 2012, 14, 82-85. doi:10.1021/ol202836p

8. Park, S. J.; Price, J. R.; Todd, M. H. J. Org. Chem. 2012, 77, 949-955. doi:10.1021/jo2021373

9. Brown, A. R.; Kuo, W.-H.; Jacobsen, E. N. J. Am. Chem. Soc. 2010 132, 9286-9288. doi:10.1021/ja103618r

10. Beaver, M. G.; Billings, S. B.; Woerpel, K. A. J. Am. Chem. Soc. 2008, 130, 2082-2086. doi:10.1021/ja0767783

11. Krumper, J. R.; Salamant, W. A.; Woerpel, K. A. Org. Lett. 2008, 10, 4907-4910. doi:10.1021/ol8019956

12. Krumper, J. R.; Salamant, W. A.; Woerpel, K. A. J. Org. Chem. 2009, 74, 8039-8050. doi:10.1021/jo901639b

13. Beaver, M. G.; Woerpel, K. A. J. Org. Chem. 2010, 75, 1107-1118. doi:10.1021/jo902222a

14. Cozzi, P. G.; Benfatti, F.; Zoli, L. Angew. Chem., Int. Ed. 2009, 48, 1313-1316. doi:10.1002/anie.200805423

15. Cozzi, P. G.; Benfatti, F. Angew. Chem., Int. Ed. 2010, 49, 256-259. doi:10.1002/anie.200905235

16. Amiralaei, S.; Gauld, J.; Green, J. R. Chem.-Eur. J. 2011, 17, 4157-4165. doi:10.1002/chem.201002685

17. Barluenga, J.; Vázquez-Villa, H.; Merino, I.; Ballesteros, A.; González, J. M. Chem.-Eur. J. 2006, 12, 5790-5805 doi:10.1002/chem.200501505

18. Matsumoto, K.; Suga, S.; Yoshida, J.-i. Org. Biomol. Chem. 2011, 9 , 2586-2596. doi:10.1039/COOB01070G

19. Mayr, H.; Ofial, A. R. Angew. Chem., Int. Ed. 2006, 45, 1844-1854. doi:10.1002/anie.200503273

20. Mayr, H.; Breugst, M.; Ofial, A. R. Angew. Chem., Int. Ed. 2011, 50, 6470-6505. doi:10.1002/anie.201007100

21. Schaller, H. F.; Tishkov, A. A.; Feng, X.; Mayr, H. J. Am. Chem. Soc 2008, 130, 3012-3022. doi:10.1021/ja0765464

22. Mayr, H.; Ofial, A. R. Pure Appl. Chem. 2009, 81, 667-683. doi:10.1351/PAC-CON-08-08-26

23. Lelais, G.; MacMillan, D. W. C. Aldrichimica Acta 2006, 39, 79-87. http://www.sigmaaldrich.com/etc/medialib/docs/Aldrich/Acta/al_acta_3 9_3.pdf

24. Erkkilä, A.; Majander, I.; Pihko, P. M. Chem. Rev. 2007, 107, 5416-5470. doi:10.1021/cr068388p
25. MacMillan, D. W. C. Nature 2008, 455, 304-308. doi:10.1038/nature07367

26. List, B. Chem. Rev. 2007, 107, 5413-5415. doi:10.1021/cr078412e

27. List, B. Angew. Chem., Int. Ed. 2010, 49, 1730-1734. doi:10.1002/anie.200906900

28. Melchiorre, P.; Marigo, M.; Carlone, A.; Bartoli, G. Angew. Chem., Int. Ed. 2008, 47, 6138-6171. doi:10.1002/anie.200705523

29. Brazier, J. B.; Evans, G.; Gibbs, T. J. K.; Coles, S. J.; Hursthouse, M. B.; Platts, J. A.; Tomkinson, N. C. O. Org. Lett. 2009, 11, 133-136. doi:10.1021/ol802512y

30. Seebach, D.; Grošelj, U.; Badine, D. M.; Schweizer, W. B.; Beck, A. K. Helv. Chim. Acta 2008, 91, 1999-2034. doi:10.1002/hlca.200890216

31. Grošelj, U.; Schweizer, W. B.; Ebert, M.-O.; Seebach, D. Helv. Chim. Acta 2009, 92, 1-13. doi:10.1002/hlca.200800432

32. Grošelj, U.; Seebach, D.; Badine, D. M.; Schweizer, W. B.; Beck, A. K.; Krossing, I.; Klose, P.; Hayashi, Y.; Uchimaru, T. Helv. Chim. Acta 2009, 92, 1225-1259. doi:10.1002/hlca.200900179

33. Seebach, D.; Grošelj, U.; Badine, D. M.; Schweizer, W. B.; Grimme, S.; Mück-Lichtenfeld, C. Helv. Chim. Acta 2010, 93, 1-16. doi:10.1002/hlca.200900376

34. Seebach, D.; Gilmour, R.; Grošelj, U.; Deniau, G.; Sparr, C.; Ebert, M.-O.; Beck, A. K.; McCusker, L. B.; Šišak, D.; Uchimaru, T. Helv. Chim. Acta 2010, 93, 603-634. doi:10.1002/hlca.201000069

35. Lakhdar, S.; Tokuyasu, T.; Mayr, H. Angew. Chem., Int. Ed. 2008, 47, 8723-8726. doi:10.1002/anie.200802889

36. Lakhdar, S.; Ofial, A. R.; Mayr, H. J. Phys. Org. Chem. 2010, 23, 886-892. doi:10.1002/poc.1737

37. Lakhdar, S.; Ammer, J.; Mayr, H. Angew. Chem., Int. Ed. 2011, 50, 9953-9956. doi:10.1002/anie.201103683

38. Alonso, E. O.; Johnston, L. J.; Scaiano, J. C.; Toscano, V. G J. Am. Chem. Soc. 1990, 112, 1270-1271. doi:10.1021/ja00159a071

39. Alonso, E. O.; Johnston, L. J.; Scaiano, J. C.; Toscano, V. G. Can. J. Chem. 1992, 70, 1784-1794. doi:10.1139/v92-223

40. Shi, L.; Horn, M.; Kobayashi, S.; Mayr, H. Chem.-Eur. J. 2009, 15, 8533-8541. doi:10.1002/chem.200901246

41. Ammer, J.; Sailer, C. F.; Riedle, E.; Mayr, H. J. Am. Chem. Soc. 2012, 134, 11481-11494. doi:10.1021/ja3017522

42. Austin, J. F.; MacMillan, D. W. C. J. Am. Chem. Soc. 2002, 124, 1172-1173. doi:10.1021/ja017255c

43. Brazier, J. B.; Hopkins, G. P.; Jirari, M.; Mutter, S.; Pommereuil, R.; Samulis, L.; Platts, J. A.; Tomkinson, N. C. O. Tetrahedron Lett. 2011, 52, 2783-2785. doi:10.1016/j.tetlet.2011.03.129

44. Ahrendt, K. A.; Borths, C. J.; MacMillan, D. W. C. J. Am. Chem. Soc. 2000, 122, 4243-4244. doi:10.1021/ja000092s

45. Paras, N. A. Enantioselective Organocatalytic Friedel-Crafts Alkylations of Heterocycles and Electron-Rich Benzenes. Ph.D. Thesis, Caltech, Pasadena, CA, 2004. http://thesis.library.caltech.edu/2353/1/NParas.pdf

46. Paras, N. A.; MacMillan, D. W. C. J. Am. Chem. Soc. 2001, 123, 4370-4371. doi:10.1021/ja015717g

47. Brown, S. P.; Goodwin, N. C.; MacMillan, D. W. C. J. Am. Chem. Soc. 2003, 125, 1192-1194. doi:10.1021/ja029095q

48. Lee, S.; MacMillan, D. W. C. J. Am. Chem. Soc. 2007, 129, 15438-15439. doi:10.1021/ja0767480

49. Kunz, R. K.; MacMillan, D. W. C. J. Am. Chem. Soc. 2005, 127, 3240-3241. doi:10.1021/ja042774b

50. Yang, J. W.; Hechavarria Fonseca, M. T.; Vignola, N.; List, B. Angew. Chem., Int. Ed. 2004, 44, 108-110. doi:10.1002/anie.200462432 
51. Ouellet, S. G.; Tuttle, J. B.; MacMillan, D. W. C. J. Am. Chem. Soc. 2005, 127, 32-33. doi:10.1021/ja043834g

52. Hayashi, Y.; Gotoh, H.; Masui, R.; Ishikawa, H. Angew. Chem., Int. Ed. 2008, 47, 4012-4015. doi:10.1002/anie.200800662

53. Mayr, H.; Ofial, A. R.; Sauer, J.; Schmied, B. Eur. J. Org. Chem. 2000, 2013-2020. doi:10.1002/1099-0690(200006)

54. Lemay, M.; Ogilvie, W. W. Org. Lett. 2005, 7, 4141-4144. doi:10.1021/ol051476w

55. Marcoux, D.; Bindschädler, P.; Speed, A. W. H.; Chiu, A.; Pero, J. E.; Borg, G. A.; Evans, D. A. Org. Lett. 2011, 13, 3758-3761. doi:10.1021/ol201448h

56. Lakhdar, S.; Mayr, H. Chem. Commun. 2011, 47, 1866-1868. doi:10.1039/COCC04295A

57. Nigst, T. A.; Westermaier, M.; Ofial, A. R.; Mayr, H. Eur. J. Org. Chem. 2008, 2369-2374. doi:10.1002/ejoc.200800092

58. Lakhdar, S.; Baidya, M.; Mayr, H. Chem. Commun. 2012, 48, 4504-4506. doi:10.1039/C2CC31224G

59. Uria, U.; Vicario, J. L.; Badia, D.; Carrillo, L. Chem. Commun. 2007, 2509-2511. doi:10.1039/B700831G

60. Enders, D.; Wang, C.; Liebich, J. X. Chem.-Eur. J. 2009, 15, 11058-11076. doi:10.1002/chem.200902236

Example for a comprehensive review on organocatalytic aza-Michael additions.

61. Maji, B.; Lakhdar, S.; Mayr, H. Chem.-Eur. J. 2012, 18, 5732-5740. doi:10.1002/chem.201103519

62. Zu, L.; Xie, H.; Li, H.; Wang, J.; Yu, X.; Wang, W. Chem.-Eur. J. 2008, 14, 6333-6335. doi:10.1002/chem.200800829

63. Appel, R.; Hartmann, N.; Mayr, H. J. Am. Chem. Soc. 2010, 132, 17894-17900. doi:10.1021/ja1084749

64. Lakhdar, S.; Appel, R.; Mayr, H. Angew. Chem., Int. Ed. 2009, 48, 5034-5037. doi:10.1002/anie.200900933

65. Mukherjee, S.; Yang, J. W.; Hoffmann, S.; List, B. Chem. Rev. 2007, 107, 5471-5569. doi:10.1021/cr0684016

66. Bertelsen, S.; Jørgensen, K. A. Chem. Soc. Rev. 2009, 38, 2178-2189. doi:10.1039/B903816G

67. Sulzer-Mossé, S.; Alexakis, A. Chem. Commun. 2007, 3123-3135. doi:10.1039/B701216K

68. Iwamura, H.; Wells, D. H.; Mathew, S. P.; Klussmann, M.; Armstrong, A.; Blackmond, D. G. J. Am. Chem. Soc. 2004, 126, 16312-16313. doi:10.1021/ja0444177

69. Clemente, F. R.; Houk, K. N. Angew. Chem., Int. Ed. 2004, 43, 5766-5768. doi:10.1002/anie.200460916

70. List, B.; Hoang, L.; Martin, H. J. Proc. Natl. Acad. Sci. U. S. A. 2004, 101, 5839-5842. doi:10.1073/pnas.0307979101

71. Bahmanyar, S.; Houk, K. N.; Martin, H. J.; List, B. J. Am. Chem. Soc. 2003, 125, 2475-2479. doi:10.1021/ja028812d

72. Bures, J.; Armstrong, A.; Blackmond, D. G. J. Am. Chem. Soc. 2011, 133, 8822-8825. doi:10.1021/ja203660r

73. Lemek, T.; Mayr, H. J. Org. Chem. 2003, 68, 6880-6886. doi:10.1021/jo0344182

74. Kaumanns, O.; Mayr, H. J. Org. Chem. 2008, 73, 2738-2745. doi:10.1021/jo702590s

75. Duan, X.-H.; Mayr, H. Org. Lett. 2010, 12, 2238-2241. doi:10.1021/ol100592j

76. Kanzian, T.; Mayr, H. Chem.-Eur. J. 2010, 16, 11670-11677. doi:10.1002/chem.201001598

77. Zenz, I.; Mayr, H. J. Org. Chem. 2011, 76, 9370-9378. doi:10.1021/jo201678u
78. Troshin, K.; Mayer, P.; Mayr, H. Organometallics 2012, 31 , 2416-2424. doi:10.1021/om3000357

79. Asahara, H.; Mayr, H. Chem.-Asian J. 2012, 7, 1401-1407. doi:10.1002/asia.201101046

80. Mayr, H.; Kempf, B.; Ofial, A. R. Acc. Chem. Res. 2003, 36, 66-77. doi:10.1021/ar020094c

81. Jensen, K. L.; Dickmeiss, G.; Jiang, H.; Albrecht, Ł.; Jørgensen, K. A. Acc. Chem. Res. 2012, 45, 248-264. doi:10.1021/ar200149w

82. Peelen, T. J.; Chi, Y.; Gellman, S. H. J. Am. Chem. Soc. 2005, 127, 11598-11599. doi:10.1021/ja0532584 See for NMR spectroscopic identification of such enamines

83. Lakhdar, S.; Maji, B.; Mayr, H. Angew. Chem., Int. Ed. 2012, 51 , 5739-5742. doi:10.1002/anie.201201240

84. Dunitz, J. D. X-Ray Analysis and the Structure of Organic Molecules; Cornell University Press: London, 1979.

85. Hayashi, Y.; Gotoh, H.; Hayashi, T.; Shoji, M. Angew. Chem., Int. Ed. 2005, 44, 4212-4215. doi:10.1002/anie.200500599

86. Franzén, J.; Marigo, M.; Fielenbach, D.; Wabnitz, T. C.; Kjærsgaard, A.; Jørgensen, K. A. J. Am. Chem. Soc. 2005, 127, 18296-18304. doi:10.1021/ja056120u

87. Brochu, M. P.; Brown, S. P.; MacMillan, D. W. C. J. Am. Chem. Soc. 2004, 126, 4108-4109. doi:10.1021/ja049562z

88. Benfatti, F.; Capdevila, M. G.; Zoli, L.; Benedetto, E.; Cozzi, P. G. Chem. Commun. 2009, 5919-5921. doi:10.1039/B910185C

89. Benfatti, F.; Benedetto, E.; Cozzi, P. G. Chem.-Asian J. 2010, 5, 2047-2052. doi:10.1002/asia.201000160

90. Gualandi, A.; Emer, E.; Capdevila, M. G.; Cozzi, P. G. Angew. Chem., Int. Ed. 2011, 50, 7842-7846. doi:10.1002/anie.201102562

91. Seebach, D.; Beck, A. K.; Badine, D. M.; Limbach, M.; Eschenmoser, A.; Treasurywala, A. M.; Hobi, R.; Prikoszovich, W.; Lindner, B. Helv. Chim. Acta 2007, 90, 425-471. doi:10.1002/hlca.200790050

92. Kanzian, T.; Lakhdar, S.; Mayr, H. Angew. Chem., Int. Ed. 2010, 49, 9526-9529. doi:10.1002/anie.201004344

93. Blackmond, D. G.; Moran, A.; Hughes, M.; Armstrong, A J. Am. Chem. Soc. 2010, 132, 7598-7599. doi:10.1021/ja102718x

94. Baidya, M.; Kobayashi, S.; Brotzel, F.; Schmidhammer, U.; Riedle, E.; Mayr, H. Angew. Chem., Int. Ed. 2007, 46, 6176-6179. doi:10.1002/anie.200701489

95. Nigst, T.; Ammer, J.; Mayr, H. J. Phys. Chem. A 2012. doi:10.1021/jp3049247 See for additional rate constants for DMAP which are not given in [94].

96. Maji, B.; Breugst, M.; Mayr, H. Angew. Chem., Int. Ed. 2011, 50, 6915-6919. doi:10.1002/anie.201102435

97. Enders, D.; Niemeier, O.; Henseler, A. Chem. Rev. 2007, 107, 5606-5655. doi:10.1021/cr068372z

98. Marion, N.; Díez-González, S.; Nolan, S. P. Angew. Chem., Int. Ed. 2007, 46, 2988-3000. doi:10.1002/anie.200603380

99. Nair, V.; Vellalath, S.; Babu, B. P. Chem. Soc. Rev. 2008, 37, 2691-2698. doi:10.1039/B719083M

100. Chiang, P.-C.; Bode, J. W. In N-Heterocyclic Carbenes: From Laboratory Curiosities to Efficient Synthetic Tools; Díez-González, S., Ed.; Royal Society of Chemistry: Cambridge, 2011; pp 399-435.

101.Zeitler, Z. Angew. Chem., Int. Ed. 2005, 44, 7506-7510. doi:10.1002/anie.200502617

102. Moore, J. L.; Rovis, T. Top. Curr. Chem. 2010, 291, 77-144. doi:10.1007/128_2008_18 
103.Nair, V.; Menon, R. S.; Biju, A. T.; Sinu, C. R.; Paul, R. R.; Jose, A.; Sreekumar, V. Chem. Soc. Rev. 2011, 40, 5336-5346. doi:10.1039/C1CS15139H

104.Biju, A. T.; Kuhl, N.; Glorius, F. Acc. Chem. Res. 2011, 44, 1182-1195. doi:10.1021/ar2000716

105. Breslow, R. J. Am. Chem. Soc. 1958, 80, 3719-3726. doi:10.1021/ja01547a064

106. Knappke, C. E. I.; Arduengo, A. J., III; Jiao, H.; Neudörfl, J.-M.; von Wangelin, J. A. Synthesis 2011, 3784-3795. doi:10.1055/s-0031-1289593

107. Maji, B.; Horn, M.; Mayr, H. Angew. Chem., Int. Ed. 2012, 51 , 6231-6235. doi:10.1002/anie.201202327

108.Biju, A. T.; Padmanaban, M.; Wurz, N. E.; Glorius, F. Angew. Chem., Int. Ed. 2011, 50, 8412-8415. doi:10.1002/anie.201103555

109.Schleyer, P. v. R.; Maerker, C.; Dransfeld, A.; Jiao, H.; van Eikema Hommes, N. J. R. J. Am. Chem. Soc. 1996, 118, 6317-6318. doi:10.1021/ja960582d

110.Matito, E.; Poater, J.; Solà, M.; Schleyer, P. v. R. In Chemical Reactivity Theory; Chattaraj, P. K., Ed.; CRC Press: Boca Raton, FL, 2009; pp 419-438.

111. Hollóczki, O.; Nyulászi, L. Org. Biomol. Chem. 2011, 9, 2634-2640. doi:10.1039/C10B00007A

112.Berkessel, A.; Elfert, S.; Etzenbach-Effers, K.; Teles, J. H. Angew. Chem., Int. Ed. 2010, 49, 7120-7124. doi:10.1002/anie.200907275

113.DiRocco, D. A.; Oberg, K. M.; Rovis, T. J. Am. Chem. Soc. 2012, 134, 6143-6145. doi:10.1021/ja302031v

114.Maji, B.; Mayr, H. Angew. Chem., Int. Ed. 2012. doi:10.1002/anie.201204524

\section{License and Terms}

This is an Open Access article under the terms of the Creative Commons Attribution License (http://creativecommons.org/licenses/by/2.0), which permits unrestricted use, distribution, and reproduction in any medium, provided the original work is properly cited.

The license is subject to the Beilstein Journal of Organic Chemistry terms and conditions:

(http://www.beilstein-journals.org/bjoc)

The definitive version of this article is the electronic one which can be found at: $\underline{\text { doi: } 10.3762 / \text { bjoc. } 8.166}$ 